\title{
Preparation of Zinc Oxide Nanoparticles using Aspergillus niger as Antimicrobial and Anticancer Agents
}

\author{
Alsayed E. Mekky* (D), Ayman A. Farrag ${ }^{1,2}$, Ahmed A. Hmed ${ }^{1}$ and Ahmed R. Sofy ${ }^{1}$ \\ ${ }^{1}$ Department of Botany and Microbiology, Faculty of Science, Al-Azhar University, Nasr City 11884, Cairo, Egypt. \\ ${ }^{2}$ Director of Al-Azhar Center for Fermentation Biotechnology and Applied Microbiology, Al-Azhar University, \\ Nasr City - 11884, Cairo, Egypt.
}

\begin{abstract}
In the current study, zinc oxide nanoparticles (ZnO-NP) were prepared using extracellular extracts of Aspergillus niger. Hence, the morphological structure, optical, and surface features of the synthesized nanoparticles were studied by $X$-ray diffraction, transmission electron microscopy, ultraviolet-visible and infrared absorption by Fourier transform. Use dynamic light scattering and zeta potential measurements to assess colloidal stability. The mean size of the synthetic particles is approximately $20 \pm 5 \mathrm{~nm}$ and they have a hexagonal crystal structure. In addition, the prepared nanoparticles have strong light absorption in the ultraviolet region of $\lambda=265$ and $370 \mathrm{~nm}$. To achieve the goal of this study, the efficiency of ZnO-NP was determined as an antibacterial and antifungal against different bacterial and fungal strains. It was found that ZnO-NP showed significant antibacterial activity, where the inhibition zones were varied from 21 to $35 \mathrm{~mm}$ in diameter against six bacterial species (i.e. K. pneumoniae, E. coli, A. baumannii, P. aeruginosa, $S$. aureus, and $S$. haemolyticus). In such a case, the minimal inhibitory concentration of zinc oxide nanoparticles against bacterial strains were 50,12.5, 12.5, 50, 12.5, and $12.5 \mu \mathrm{g} / \mathrm{ml}$ for K. pneumoniae, E. coli, A. baumannii, P. aeruginosa, S. aureus, and S. haemolyticus, respectively. Furthermore, $\mathrm{ZnO}$-NP exhibits an antifungal behaviour against four fungal species (i.e., $A$. niger, P. marneffei, C. glabrata, and C. parapsilosis) with inhibition zone from 18 to $35 \mathrm{~mm}$ in diameter. Whereas, the MICs for fungal isolates were $12.5 \mu \mathrm{g} / \mathrm{ml}$ except $A$. niger was at $25 \mu \mathrm{g} / \mathrm{ml}$. Wi-38 cells were treated with ZnO-NPs exhibited different levels of cytotoxicity dependent upon the concentration of ZnO NPs using the MTT assay with $\mathrm{IC}_{\mathbf{5 0}} \mathbf{8 0 0 . 4 2}$. Therefore, the present study introduces a facile and cost-effective extracellular green-synthesis of ZnO-NP to be used as antimicrobial and anticancer agents.

Keywords: Zinc oxide nanoparticles, extracellular green synthesis, nanoparticles characters, anti-bacterial and antifungal
\end{abstract}

\section{*Correspondence: mekkysayed26@gmail.com; alsayedessam@azhar.edu.eg}

(Received: June 21, 2021; accepted: August 05, 2021)

Citation: Mekky AE, Farrag AA, Hmed AA, Sofy AR. Preparation of Zinc Oxide Nanoparticles using Aspergillus niger as Antimicrobial and Anticancer Agents. J Pure Appl Microbiol. 2021;15(3):1547-1566. doi: 10.22207/JPAM.15.3.49

(C) The Author(s) 2021. Open Access. This article is distributed under the terms of the Creative Commons Attribution 4.0 International License which permits unrestricted use, sharing, distribution, and reproduction in any medium, provided you give appropriate credit to the original author(s) and the source, provide a link to the Creative Commons license, and indicate if changes were made. 


\section{INTRODUCTION}

Recently, in the presence of extracellular or intracellular extracts of microorganisms such as bacteria, fungi, and yeast strains, the biosynthesis of nanostructures has attracted attention due to its ease of preparation, photoelectric and physicochemical properties; in addition, it has excellent antimicrobial activity ${ }^{1-4}$. Although the reduction rate of metal ions in nanoparticles is faster, the existence of extracellular extracts (i.e. plants and microorganisms) is much faster under environmental conditions of temperature and pressure $^{5-7}$. Several studies have been devoted to improving the synthetic efficiency such as control of particle size, shape, and mono-dispersity ${ }^{8-10}$. Zinc oxide $(\mathrm{ZnO})$ is an inorganic metal oxide that has a wide range of applications, such as medicines and cosmetics, and is mainly used to fight infections in the form of ointments and creams. Similarly, ZnONPs combined with other metal oxides (such as $\mathrm{SiO}_{2} \mathrm{NPs}$ ) is used as UV blockers in textiles and induce superhydrophobicity and bacterial growth inhibitory properties ${ }^{11-13}$. In addition, ZnO NPs are widely used as an additive in ceramics, glass, cement, rubber, lubricants, paints, ointments, adhesives, pigments, foods, batteries, first-aid tapes, etc. ${ }^{14,15}$. Moreover, ZnO NPs have higher catalytic efficiency, and chemical stability, the antimicrobial mechanism of $\mathrm{ZnO}$ NPs is still open and not well known. Some authors suggest that ZnO NPs didn't exhibit any antimicrobial activity by themselves, but enhances the antimicrobial activity of certain antibiotics ${ }^{16}$. The antimicrobial effects of $\mathrm{ZnO}$ NPs against many foodborne pathogens have been reported, such as E. coli $0157: \mathrm{H}^{17}$, C. jejuni ${ }^{18}$, P. aeruginosa ${ }^{19}$, Salmonella spp. ${ }^{20}$ and Staphylococcus aureus ${ }^{21}$. In addition, ZnO-NPs have antibacterial efficacy against both the Gram-negative and Gram-positive bacteria and many viruses such as Escherichia coli, Streptococcus pyogenes, Staphylococcus aureus, Enterococcus faecalis, Bacillus subtillis, B. atrophaenus, Salmonella typhimurium, Klebisella pnumoniae, Alfalfa mosaic virus, etc. ${ }^{22-26}$. Furthermore, ZnO-NPs have antifungal activity against several types of molds such as Aspergillus flavus and A. fumigatus and many other microscopic molds, such as Botrytis cinerea, Penicillium expansum, Phanerochaete salmonicolor, Candida albicans, and Fusarium oxysporum $^{27,28}$. Up-to-date, some studies have been devoted to reporting that fungal-mediated synthesis is more advantageous because fungi are super accumulators, showing economic viability and easy expansion of synthesis ${ }^{29,30}$. Furthermore, a large number of extracellular proteins and enzymes have the dual function of producing and coating mono-disperse nanoparticles ${ }^{31}$. In addition, fungi are very tolerant of higher concentrations of metals and, due to the presence of a large number of extracellular proteins and redox enzymes; they have a large number of functional groups that can reduce metal ions to zero-valence metal nanoparticles ${ }^{32}$. The cytotoxic mechanism of ZnO-NPs is not yet fully understood, but hydroxyl radicals $\left(\mathrm{OH}^{\circ}\right)$, superoxide anions $\left(\mathrm{O}_{2}{ }^{-}\right.$ ), and per-hydroxyl radicals $\left(\mathrm{HO}_{2}{ }^{\circ}\right)$ generated from the surface of $\mathrm{ZnO}$ are believed to be the main components. When Nanoparticles interact with cells, cellular protection mechanisms are activated to minimize damage; however, if the production of highly active free radicals more exceeds the cell's antioxidant defence capabilities, biomolecules will undergo oxidative damage, leading to cell death $^{33,34}$.

In this study, green $\mathrm{ZnO}$ nanoparticles have been synthesized by using extracellular proteins and enzymes present in Aspergillus niger extract to reduce $\mathrm{Zn}^{2+}$ present in zinc acetate as a metal precursor. In addition, antimicrobial agents will be studied, including antibacterial and fungal activity against bacterial and fungal species.

\section{Experimental Section}

Materials

Zinc acetate salt $\left(\mathrm{Zn}\left(\mathrm{CH}_{3} \mathrm{COO}\right)_{2}\right)$ was pursued from Sigma-Aldrich, Whatman filter paper. Glassware was washed with sterile distilled water more than one time then dried in an electric oven before using to remove any contaminations. Muller-Hinton agar ${ }^{35}$, Nutrient Agar medium ${ }^{36}$. Nutrient Broth medium ${ }^{37}$, Potato Dextrose Agar $(P D A)^{38}$ and Potato Dextrose Broth (PDB) ${ }^{39}$, from Sigma Aldrich- Germany.

\section{Methods}

Isolation and purification of fungal isolates

Soil samples were taken from the garden of the Botany and Microbiology Dep., Faculty of Science, Al-Azhar University, Cairo, Egypt, at approximately $10 \mathrm{~cm}$ depth. One gram of soil sample collected was suspended 
in $100 \mathrm{ml}$ of distilled and sterilized water. One milliliter $(1 \mathrm{ml})$ from $10^{-1}$ to $10^{-6}$ dilutions of soil suspension of the sample was placed on the plate ${ }^{40}$, with media Czapex-Dox Agar (CDA) media g/L: Sucrose: $30 \mathrm{~g}$. $\mathrm{NaNO}_{3}: 2 \mathrm{~g}$, , $\mathrm{KH}_{2} \mathrm{HPO}_{4}: 1 \mathrm{~g}$. $\mathrm{KCl}: 0.5 \mathrm{~g} . \mathrm{MgSO}_{4} .7 \mathrm{H}_{2} \mathrm{O}: 0.5 \mathrm{~g}$, $\mathrm{FeSO}_{4} .7 \mathrm{H}_{2} \mathrm{O}: 0.01 \mathrm{~g}$, Agar: $20 \mathrm{~g}$, and distilled water: $1000 \mathrm{ml}, \mathrm{pH}$, supplemented with chloramphenicol $0.5 \%$ to suppress bacterial growth ${ }^{41}$. A triplicate of plates was used for each particular dilution. Then, the plates were incubated for seven days at $27 \pm 2^{\circ} \mathrm{C}$ until colonies appeared. The isolation of fungi was carried out by using a CDA medium according to the method described by ${ }^{42}$.

\section{Identification of most potent fungal isolate} Morphological, cultural and microscopic examination for fungal isolate

A Purified fungal isolate was identified based on routine cultural and morphological characteristics. Fungal genera and species were identified according to standard manuals $\mathrm{s}^{43,44}$. Macroscopic examinations were carried out to study the culture characteristics, including colony surface color, reverse color, colony growth rate, and pigmentation.

\section{Molecular identification for fungal isolate}

Use the Easy Pure Genomic DNA Extraction Kit to isolate DNA samples from the tested fungal strains, and use Nano-Drop to measure the purity and appropriate concentration of the DNA samples. Four samples of Aspergillus niger DNA for PCR reactions. Two fungal universal primers, FW 5-ATGGGCAAGGCACCAAATAA-3 and RW 5-TGGAAATGGATC CAAGAATG-3 were used to carry out the PCR reaction of 4 fungal 18s rDNA gene amplification. The PCR reaction conditions were adjusted to $40 \mathrm{ng}(6 \mu \mathrm{l})$ DNA template (fungi) and $8.5 \mu \mathrm{l}$ master mix, which includes a mixture of dNTP, $\mathrm{MgCl}_{2}$, Taq polymerase, and PCR buffer. Add primers separately after preparation from the lyophilized stock solution (each primer is 1 $\mu \mathrm{mol} / \mathrm{l})$. The PCR conditions were adjusted for the denaturation step of $92.3^{\circ} \mathrm{C}$, the hybridization step of $55.6^{\circ} \mathrm{C}$ and the extension step of $71.9^{\circ} \mathrm{C}$. The number of PCR cycles was 36 cycles, and the El-Dokki PCR thermal cycler from the National Research Center (NRC) of Giza, Egypt was used. Use a $1 \%$ agarose gel to separate the amplified DNA product and, DNA markers [Gene Ruler 100 bp DNA Ladder (SM0241)] by electrophoresis.
The gel was stained with ethidium bromide and the band profile was recorded using the UV gel documentation system. Purify, and sequence the amplified DNA products. The 4 sequences were analyzed and tested against the most closed sequence in Gen Bank NCBI through BLST, and the phylogenetic tree was designed using MEGA 7 software.

\section{Preparation of fungal biomass extract}

A Purified fungal isolate was tested for ZnO NP biosynthesis by growing in Czapex Dox broth $(C B D)^{45}$. Two discs $(0.7 \mathrm{~mm})$ of purified fungal isolates were freshly incubated in $50 \mathrm{ml}$ of CBD in a $250 \mathrm{ml}$ Erlenmeyer flask as a fermentation medium. Incubate at rpm for 6 days. The fungal biomass is collected by passing through two layers of medical gauze and washed with distilled and sterile water to remove any adhering medium components. Then, ten (10) g of fungal biomass were suspended in $100 \mathrm{ml}$ of distilled water in a $250 \mathrm{ml}$ Erlenmeyer flask and stirred at $150 \mathrm{rpm}$ at $28 \pm 2^{\circ} \mathrm{C}$ for 72 hours. Then, the cells were discarded by Whatman No. 1 filter paper to obtain a biomass filtrate for nanoparticle synthesis.

\section{Extracellular green synthesis of Zinc oxide nanoparticles using fungal isolates}

Typically, in a $250 \mathrm{ml}$ reaction vessel, an equi-volume ratio (1:1) aqueous solution of zinc acetate $\left(1 \mathrm{mM} / 100 \mathrm{ml}, \mathrm{Zn}\left(\mathrm{CH}_{3} \mathrm{COO}\right)_{2}\right)$ was added to $100 \mathrm{ml}$ of fungal extract filtrate under orbital shaking at $150 \mathrm{rpm}$. The reaction was incubated at $\mathrm{pH} \sim 6.5$, and a temperature of $32^{\circ} \mathrm{C}$ for $72 \mathrm{hr}$. in dark conditions. A white precipitate is formed indicating to the formation of ZnONPs. The asprepared ZnONPs were washed several times with sterile distilled water then centrifuged at 10,000 rpm for $10 \mathrm{~min}^{46}$.

\section{Characterization}

Use the JASCO 730 Double Beam Spectrophotometer to obtain the optical UVVis absorption characteristics. The absorption spectrum was recorded in the range of 200 to $900 \mathrm{~nm}$ and the increase in wavelength was approximately $0.2 \mathrm{~nm}$. The JEOL Transmission Electron Microscope (TEM), model 1200EX, is used to study micrographs of samples obtained at an operating voltage of $120 \mathrm{kV}$. In addition, the Ultima IV powder diffractometer (Rigaku) has been used for X-ray diffraction (XRD) measurements in the 2 rango range of 20-70 degrees using a $\mathrm{Cu}$ 
objective with $\mathrm{K} \alpha 1=1.54060 \AA$. X-ray scanning is performed in a $2 \theta / \theta$ continuous mode at a speed of 2 degrees per minute with a step size of 0.02 . The tube voltage and tube current are maintained at $40 \mathrm{kV}$ and $40 \mathrm{~mA}$. It Uses the Malvern Zetasizer Nano (ZS) instrument and He/Ne laser (633 nm) to collect backscattering optics at an angle of $173^{\circ}$ to measure the size distribution and zeta potential of the sterilized ZnONP. In addition, according to Vivek et al. ${ }^{47}$, the JASCO 6700 Fourier Transform Infrared Spectrometer (FT-IR) was used to obtain the FT-IR of green synthetic ZnONP in the range of 400 to $4000 \mathrm{~cm}^{-1}$.

\section{Antimicrobial property \\ Tested microorganisms \\ Bacteria}

Six isolates, Klebsiella pneumoniae, Escherichia coli, Acinitobacter baumannii, Pseudomonas aeruginosa, Staphylococcus aureus, and Staphylococcus haemolyticus were isolated from clinical samples and identified based on culture, morphology, and biochemical analysis according to Bergey's manual ${ }^{48}$. In addition, a Vitek2 system was carried out to confirm the identity.

\section{Fungi/Yeast}

Four isolates were Aspergilus niger, Penicillium marneffei, Candida glabrata, and Candida parapsilosis isolated from clinical samples and identified in the Mycology Lab. of the Botany and Microbiology Dep. Faculty of Science, Al-Azhar University, Cairo, Egypt.

\section{Antimicrobial Experiments}

The zinc oxide nanoparticles (ZnO-NPs) synthesized from Aspergillus niger biomass were tested for antimicrobial activity via two methods; the agar-well diffusion method and the broth micro-dilution assay.

\section{Agar well diffusion method}

Apure cultures of the tested bacteria were sub-cultured in nutrient broth and each strain was uniformly spread on sterilized petri plates with Muller-Hinton agar. A circular well of $6 \mathrm{~mm}$ in diameter was made in plates using a sterile cork-borer. Each well was loaded with $(50 \mu \mathrm{l})$ ZnO-NPs to check the antibacterial activity and the plates were incubated at $37^{\circ} \mathrm{C}$ overnight and the zones of inhibition were measured. Additionally, the antifungal activity of zinc oxide nanoparticles was examined against tested fungal species. The strains were maintained on $\mathrm{CDA}$ at $28^{\circ} \mathrm{C}$ and $5-\mathrm{d}$ old cultures were used for antifungal analysis. Pour three to four milliliters of sterile normal saline onto the fungal growth; gently scrape to collect the conidia. Spread $100 \mu \mathrm{l}$ of this liquid spore suspension evenly on a fresh potato dextrose agar (PDA) plate. Use a sterile cork-borer to make a 6 $\mathrm{mm}$ in diameter circular hole in the plate. Each well was filled with $(50 \mu \mathrm{l})$ zinc oxide nanoparticles to check antifungal activity, then incubated the plate at $25^{\circ} \mathrm{C}$ for $2-3$ days and measured the zone of inhibition ${ }^{49}$.

\section{Broth microdilution assay}

The suspension was turbid to 0.5 McFarland standards $\left(10^{8} \mathrm{cfu} / \mathrm{ml}\right)$ produced by fresh subcultures of bacterial and fungal/yeast Mueller Hinton Broth (MHB) and Potato Dextrose Broth (PDB), respectively. The corresponding suspension was diluted to $10^{6} \mathrm{cfu} / \mathrm{ml}$. Prepared microbial inoculation $(100 \mu \mathrm{l})$ was added to each well of a sterile flat bottom 96-well microtiter plate containing the tested concentrations of $\mathrm{ZnO}$ NP $(100 \mu \mathrm{l} /$ well $)$. As a result, a final inoculation concentration of $5 \times 105 \mathrm{cfu} / \mathrm{ml}$ was obtained from each well. The tested ZnO-NP used in the growth control of the tested microorganisms was contained in wells containing microbial suspensions and other well plates containing double background control. The optical density was measured at $620 \mathrm{~nm}$ after 24 hours at $37^{\circ} \mathrm{C}$ for bacteria, 48 hours at $28^{\circ} \mathrm{C}$ for mold / yeast, using an ELISA microplate reader (Sunrise ${ }^{\mathrm{TM}}$ -TECAN, Switzerland) at the Faculty of Science AlAzhar University in Cairo, Egypt. Finally, the cell concentration was converted to an average growth inhibition percentage (\%). The rate of decrease in microbial growth (GR \%) was estimated as follows, based on the treatment of the control group (excluding the ZnONPs). GR\% = CT / C x100 where $\mathrm{C}$ is the treated cell concentration of the control group and $\mathrm{T}$ is the ZnONPs process. Three replicas were considered. The Results were reported as the mean \pm SE of the experiments $5^{50}$.

\section{Preparation of Resazurin Solution}

The concentration of resazurin stain solution is $0.02 \%(\mathrm{w} / \mathrm{v})^{51}$. Dissolve $0.002 \mathrm{~g}$ of resazurin stain salt fine powder in $10 \mathrm{ml}$ of sterile distilled water and vortex. The complete mixture is filtered through a Millipore membrane filter (0.2 $\mu \mathrm{m})$. This solution can be stored at $4^{\circ} \mathrm{C}$ for 2 weeks. 


\section{Determination of Minimum Inhibitory Concentration (MIC)}

The minimum inhibitory concentration of biosynthesized ZnO NPs was evaluated against bacterial and fungal strains via a method described in the guide ${ }^{50}$. The MIC test is evaluated on a 96well microtiter plate with a round bottom by a standard broth microdilution assay.

For bacterial strains; the concentration of the bacterial inoculum was adjusted to 106 $\mathrm{cfu} / \mathrm{ml}$. Add $100 \mu \mathrm{l}$ of biosynthesized ZnO-NPs stock solution $(400 \mu \mathrm{g} / \mathrm{mL})$ to the first well, dilute 2 times with the bacterial inoculum, and use 100 $\mu \mathrm{L}$ media MHB from column 4 to column 12 . The fourth column of the plate contains the highest concentration of $\mathrm{ZnO} \mathrm{NP}$, while the 12th column has the lowest concentration. Column 1 serves as a positive control (medium and bacterial inoculum), and column 2 serves as a negative control (medium only). Add $30 \mu$ resazurin solutions to each well of the microtiter plate and incubate for $24 \mathrm{~h}$ at $37^{\circ} \mathrm{C}$. A color change is observed. Blue/purple means no bacterial growth, while pink/colorless means bacterial growth. The MIC value is obtained at the lowest concentration of the antibacterial agent that inhibits the growth of bacteria, the color remains blue.

For fungal strains, a suspension of the original inoculum in sterile saline containing $1 \%$ Tween 80 (supplied by Trek Diagnostic Systems) was prepared from 7-day old cultures grown on a PDA slope. For an inoculation density of $95 \%$, the actual stock inoculation suspension calculated by quantifying the inoculation varies between $0.9 \times$ $10^{6}$ and $4.5 \times 10^{6} \mathrm{cfu} / \mathrm{ml}$. One hundred $(100 \mu \mathrm{l})$ biosynthesized ZnO NPs stock solution $(400 \mu \mathrm{g} / \mathrm{mL})$ was added to the first well of another new plate (96-well microtiter plate with a round bottom). Followed by a $100 \mu$ l of fungal conidia inoculum suspension in liquid potato dextrose agar (PDA) was added. The microdilution tray is incubated at $30^{\circ} \mathrm{C}$ and checked after 4 days of incubation. The endpoint of MIC is the lowest concentration of ZnNP showing no growth or complete inhibition of growth (100\% inhibition) $)^{52}$. On the other hand, as described above, unicellular fungi are evaluated as bacteria.

Cytotoxicity assay to evaluate nanoparticles toxicity by using tissue culture

According to Riss and Moravec ${ }^{53}$ (MTT protocol), the culture plate with (96-well tissue) was cultivated with $1 \times 10^{5}$ cells/ml (100 $\mu \mathrm{l} /$ well) and incubated for 24 hours at $37^{\circ} \mathrm{C}$ to form an integrated monolayer. After forming a collected cell sheet, pour out the growth medium from the 96-well microtiter plate, and the cell monolayer was washed twice with a washing medium (duple dilution) in a medium containing $2 \%$ serum (maintenance medium). $0.1 \mathrm{ml}$ of each dilution test was prepared in different wells, 3 wells were left as controls, and only contained medium. Incubate the plate at $37^{\circ} \mathrm{C}$. Check the cells for any changes that indicate physical toxicity, such as partial or complete damage of monolayer, shrinkage, rounding, or granulation of the cells. 20ul of MTT solution was added to each well, then shacked for 5 minutes at $150 \mathrm{rpm}$ to optimum mix the MTT in the medium completely, then incubated for $1-5$ hours at $37^{\circ} \mathrm{C}$ and $5 \% \mathrm{CO}_{2}$ to let the MTT metabolize. Then remove the medium, dry the towel if necessary to remove debris, resuspend the formazan (metabolic product MTT) in $200 \mathrm{ul} \mathrm{DMSO}$, and shake it for 5 minutes at 150 rpm to remove the formazan mixed thoroughly into the medium. Finally, record the optical density at a wavelength of $560 \mathrm{~nm}$ and subtract the background at 620 nanometers. The optical density must be directly related to the number of cells.

\section{Statistical analysis}

All the experiments were performed in triplicate and data were analysed. Analyses were performed as prescribed by Kareem et al. ${ }^{54}$.

\section{RESULTS AND DISCUSSION}

Identification of Fungal Isolates

\section{Cultural and morphological characterization}

The obtained results showed that the isolate (MEKKY A1) belonged to Aspergillus niger. Cultural and morphological characterization data are depicted in Table 1 and Fig. 1. The colonies' diameter was in the range of $35-40 \mathrm{~mm}$ after incubation for 4 days at $30^{\circ} \mathrm{C}$. Rapid rate growth with black or brownish black appearance in observed colour and Pale begin reverse colour. Conidia are spherical, rough walled, 2-5 $\mu \mathrm{m}$ in size. The sterigmata were Biseriate, (Metulae and Phialides), vesicle globose in shape 40.0-60.0 $\mu \mathrm{m}$, conidial heads with a radial shape, and the conidiophore was 11.9-19.9 $\mu \mathrm{m}$ in diameter, up to 
Table 1. Culture and microscopic characteristics of fungal isolate (MEKKY A1) growing on CYA

\begin{tabular}{|c|c|}
\hline Character & Examination \\
\hline \multicolumn{2}{|c|}{ Culture Examination } \\
\hline $\begin{array}{l}\text { Growth } \\
\text { characteristics }\end{array}$ & $\begin{array}{l}\text { Colonies grow moderately with } 35- \\
40 \mathrm{~mm} \text { in diameter in } 4 \text { days at } 30^{\circ} \mathrm{C} \\
\text { on CYA, with black or brownish black. } \\
\text { Reverse was pale beige. }\end{array}$ \\
\hline \multicolumn{2}{|c|}{ Microscopic Examination } \\
\hline Conidiophore & $\begin{array}{l}11.9-19.9 \mu \mathrm{m} \text { in diameter, up to } \\
4.0 \mathrm{~mm} \text { extent }\end{array}$ \\
\hline Vesicle & Globose shape $40.0-60.0 \mu \mathrm{m}$ \\
\hline Sterigmata & Biseriate, (Metulae and Phialides) \\
\hline Conidia & Spherical, rough walled 2-5 $\mu \mathrm{m}$. \\
\hline Conidial heads & Radiate shape. \\
\hline
\end{tabular}

$4.0 \mathrm{~mm}$ in extent. From previous data, the fungal isolate (MEKKY A1) followed the Aspergillus sp.

Molecular identification of the most potent fungal isolate

Phylogenetic analysis of isolate (MEKKY A1) suggested that this isolate have high similarity
(99\%) with strain Aspergillus niger. The sequence obtained from the current study was deposited under accession number MT645619.1 in Gene Bank for Aspergillus Fig. 2.

Synthesis and characterization of extracellular synthesized zinc oxide nanoparticles

Using fungal biomass from $A$. niger, ZnO-NPs were completely synthesized outside the fungal cell. In this process, the formulation of ZnO-NP is determined through the formation of a white precipitate at the end of the reaction. This is due to the reduction of $\mathrm{Zn}^{2+}$ ions in zinc acetate in $\mathrm{ZnO}-\mathrm{NP}$ in the presence of an aqueous medium, (Fig. 3). The fungal filtrate from the fungal isolate acts as both a reducing and a protective agent.

This is due to the presence of a set of extracellular proteins and enzymes. Jane et al. ${ }^{55}$ A. aeneus, as a stabilizer, was found to synthesize spherical ZnO nanoparticles coated with protein molecules. Furthermore, they showed that the fungal extracellular proteins' role in the synthesis of nanoparticles suggests that the biosynthesis process is not enzymatic, but involves amino acids found in the protein chain.
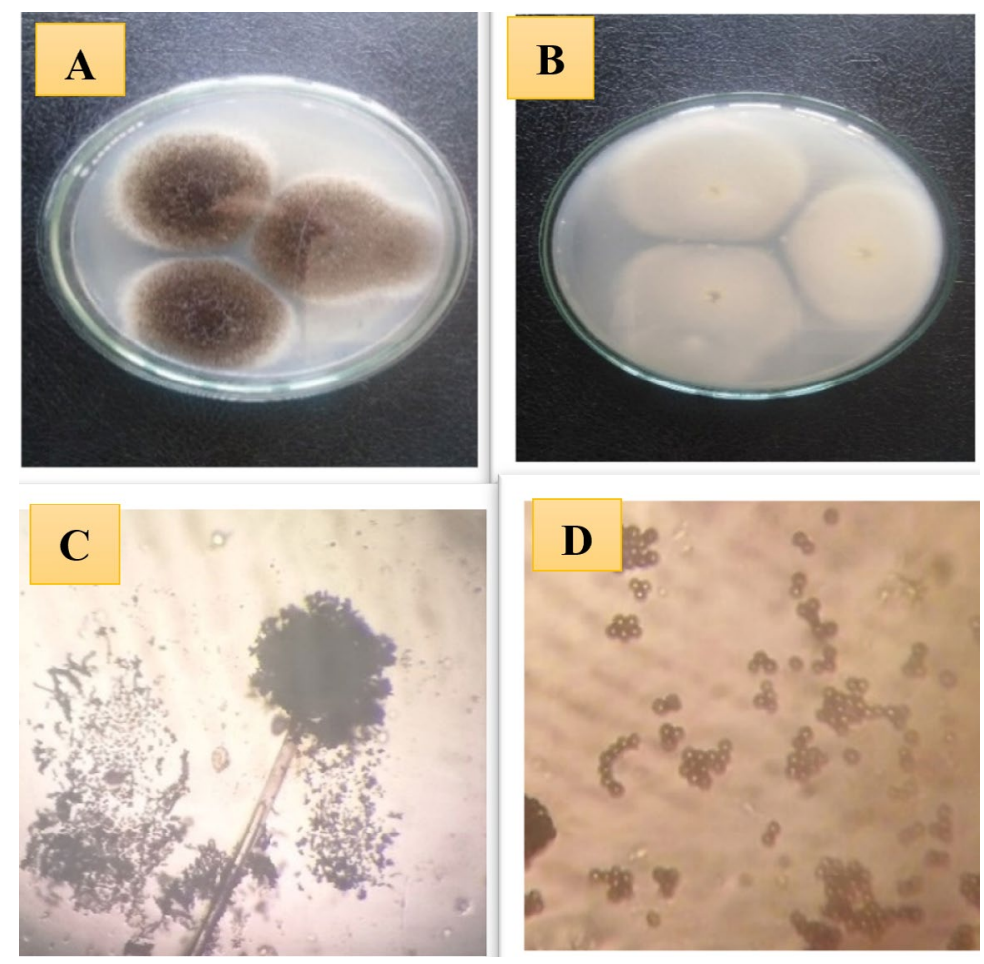

Fig. 1. Morphological and microscopic characteristic of fungal isolate (MEKKY A1) Aspergillus sp. (A) colony of fungal isolate Aspergillus sp. on CYA, (B) reverse colony of fungal isolate Aspergillus sp., (C and D), bright field microscope $(X=20 \times 40)$. 
Several authors showed that $A$. fumigatus ${ }^{56}, A$. niger $^{57}$, F. oxysporum ${ }^{58}$ and P. citrinum ${ }^{59}$, have the ability to synthesize nanoparticles from metal salts.
Moreover, the formation of the biosynthesized zinc oxide nanoparticles was confirmed using UV-Vis spectroscopy measurements shown in Fig. 4.

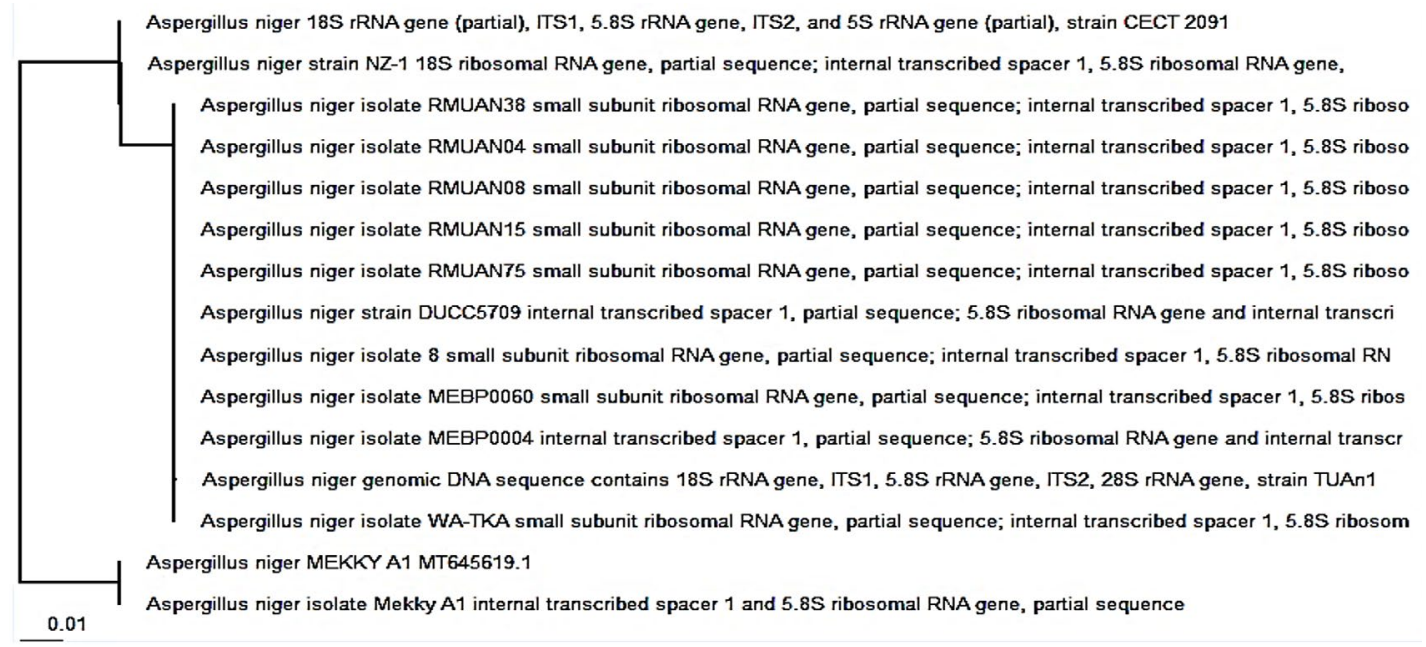

Fig. 2. Phylogenetic tree of gene sequences of the Aspergillus niger isolate with the sequences retrieved from NCB Gene Bank site.

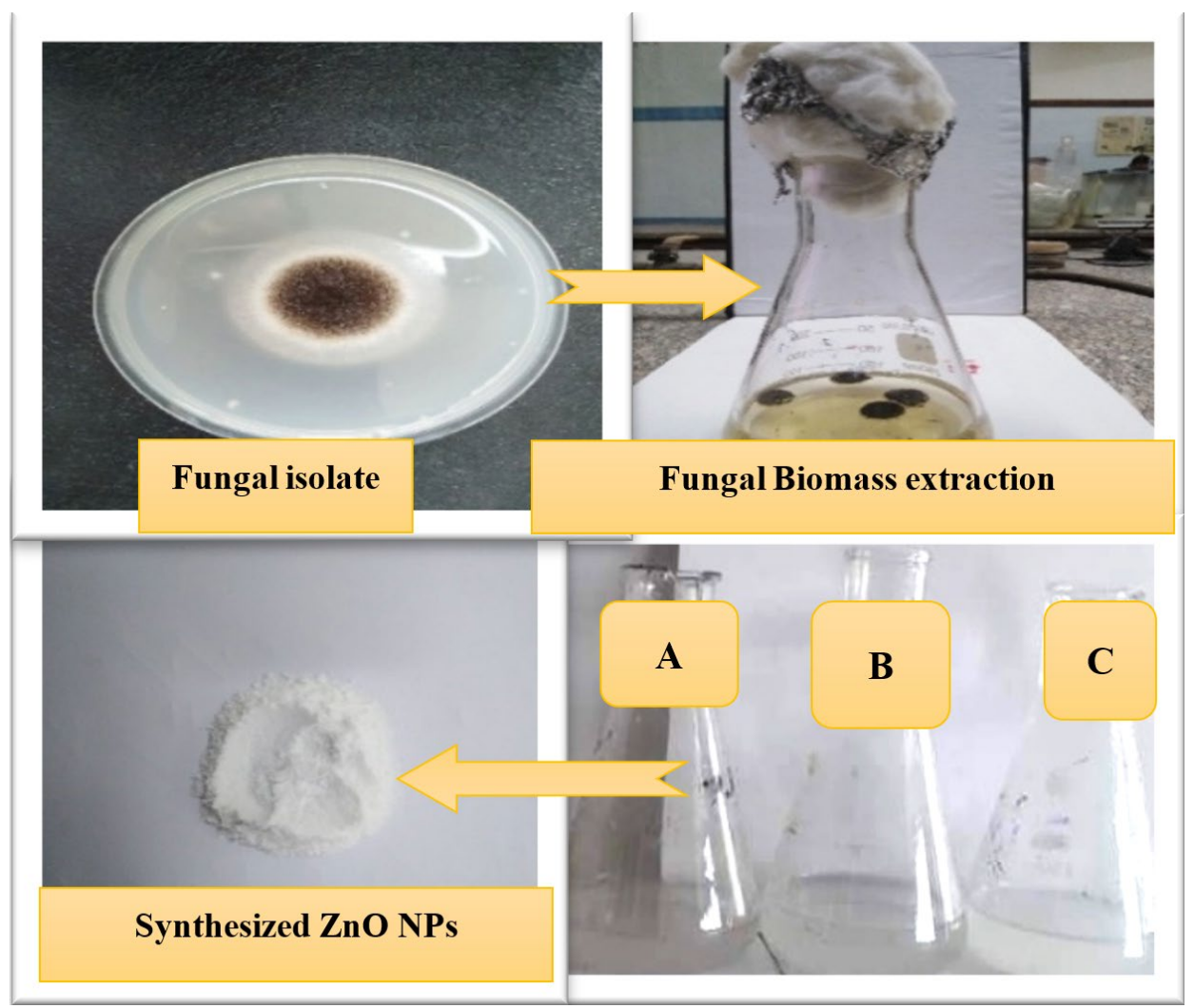

Fig. 3. Scheme for extracellular synthesis of ZnO NPs, (A) fungal biomass extract, (B) Zinc acetate solution and (C) synthesized ZnOPs solution. 
ZnO-NPs showed strong absorption bands at 265 and $370 \mathrm{~nm}$ in the ultraviolet region, indicating the formation of ZnO-NPs. The morphology and structural characteristics of the prepared $\mathrm{ZnO}$ NPs were confirmed by TEM and XRD, as shown in Figure 5 and 6, respectively. TEM micrographs show that ZnO NPs are quasi-spherical without any agglomeration and have a polydispersity distribution. The average particle size is about $20 \pm 5 \mathrm{~nm}$ Fig. 5. The XRD pattern shown in Fig. 6 shows three stronger and narrower reflections near $2 \theta 31.7^{\circ}, 34.5^{\circ}$, and $36.2^{\circ}$, indicating that the lattice spacing (dhkl) is $2.81,2.6$, and $2.5 \AA$, which respectively revealed the (100), (002), (101) crystal reflections of the hexagonal structure (hcp) of zinc oxide atoms (reference code 010890510) ${ }^{60}$.

Furthermore, the colloidal stability of $\mathrm{ZnO}$ NP has been studied using dynamic light scattering technology (DLS) and zeta potential measurement, as shown in Table 2. The hydrodynamic diameter (HD) of the ZnO NPs prepared in the solution carrier is approximately $680.7 \pm 84.79 \mathrm{~nm}$, and the polydispersity index (PDI) is 0.908 , indicating that the polydisperse particles aggregate because of the high hydrophilicity of the ZnO-NPs prepared ${ }^{61}$, as shown in Fig. (7a) and Table (2) However, the zeta potential $(n)$ of ZnO NPs prepared from Aspergillus niger extracellular extracts is approximately -14.4

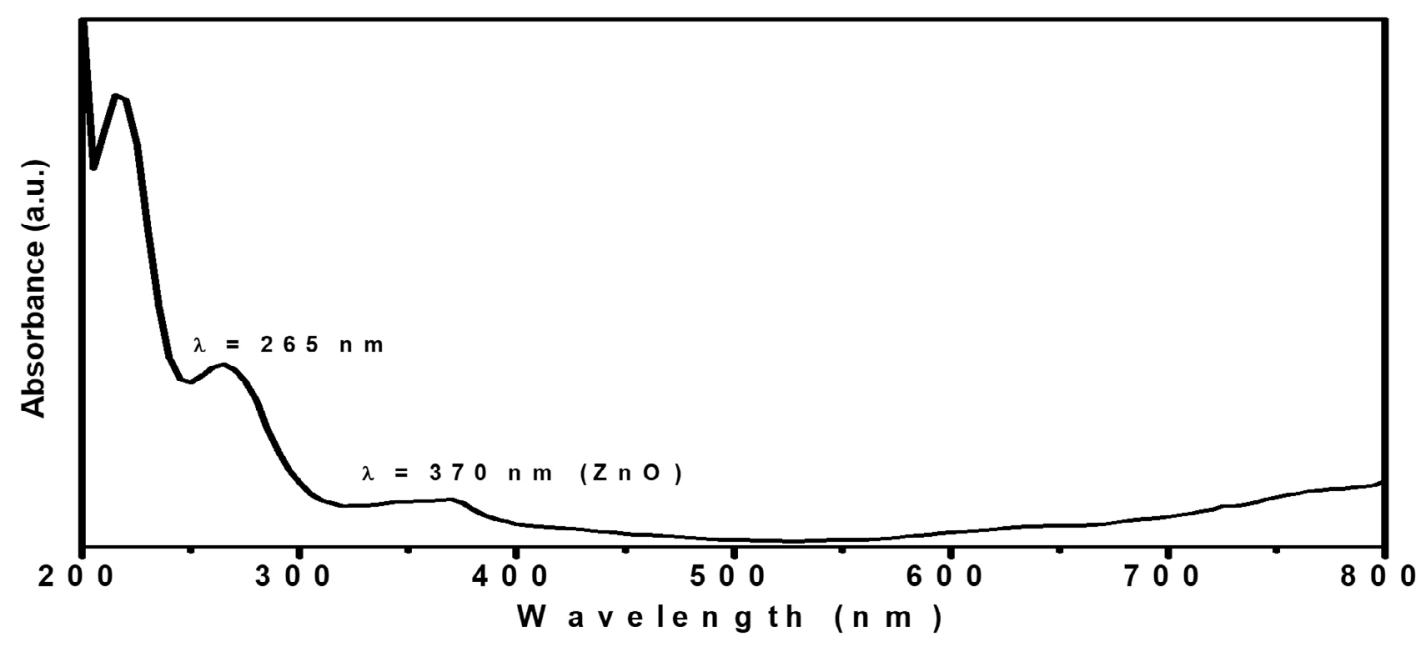

Fig. 4. The spectra of UV-Vis absorption of green synthesized ZnO NPs using (A. niger) extracellular extract.

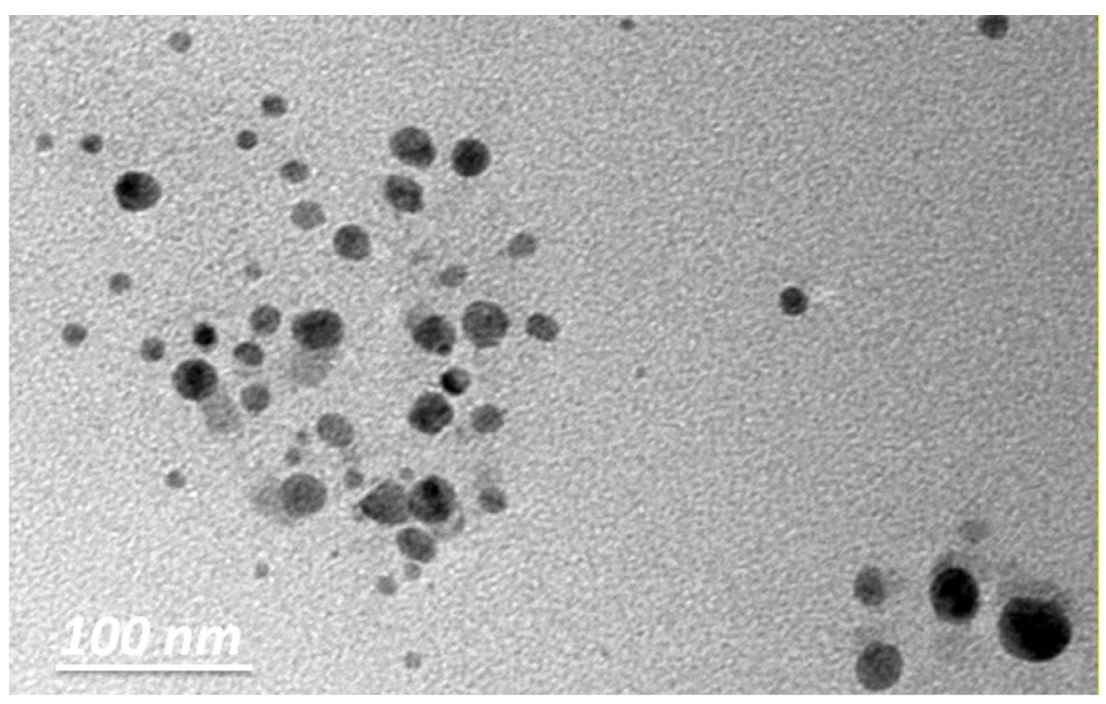

Fig. 5. TEM micrographs at scale bar $100 \mathrm{~nm}$ of green synthesized ZnO-NPs using (A. niger) extracellular extract. 
$\pm 4.75 \mathrm{mV}$ (Fig. 7a. 7b, Table 2). Negative values indicate the stabilization of nanoparticles and prevent the clustering of nanoparticles ${ }^{62}$. The negative potential value may be due to the capping

Table 2. DLS and zeta-potential measurements of green synthesized ZnO NPs

\begin{tabular}{lccc}
\hline Sample Name & $\begin{array}{c}\text { DLS Data } \\
\text { Hydrodynamic } \\
\text { Diameter (HD, nm) }\end{array}$ & $\begin{array}{c}\text { Polydispersity } \\
\text { Index (PDI) }\end{array}$ & $\begin{array}{c}\text { Zeta-potential } \\
(\mathrm{n}, \mathrm{mV})\end{array}$ \\
\hline Zinc oxide (ZnO) & $680.7 \pm 84.79 \mathrm{~nm}$ & 0.908 & $-14.4 \pm 4.75$ \\
\hline
\end{tabular}

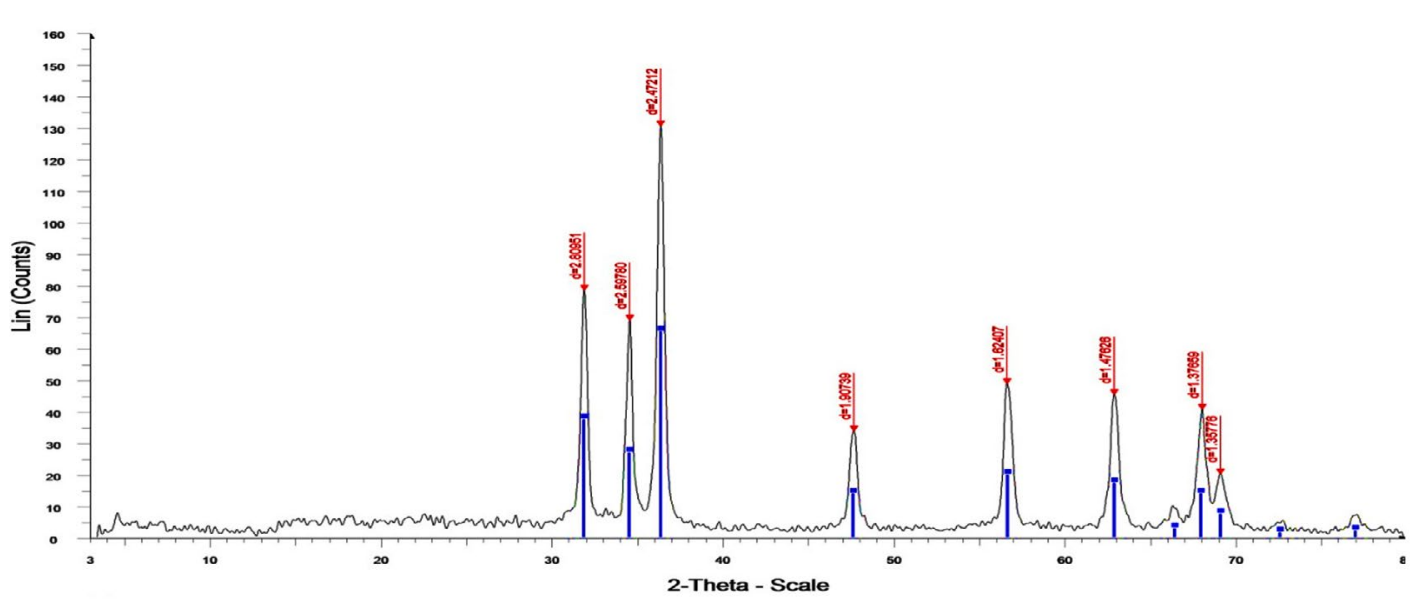

Fig. 6. XRD patterns of green synthesized ZnO-NPs using (A. niger) extracellular extract.

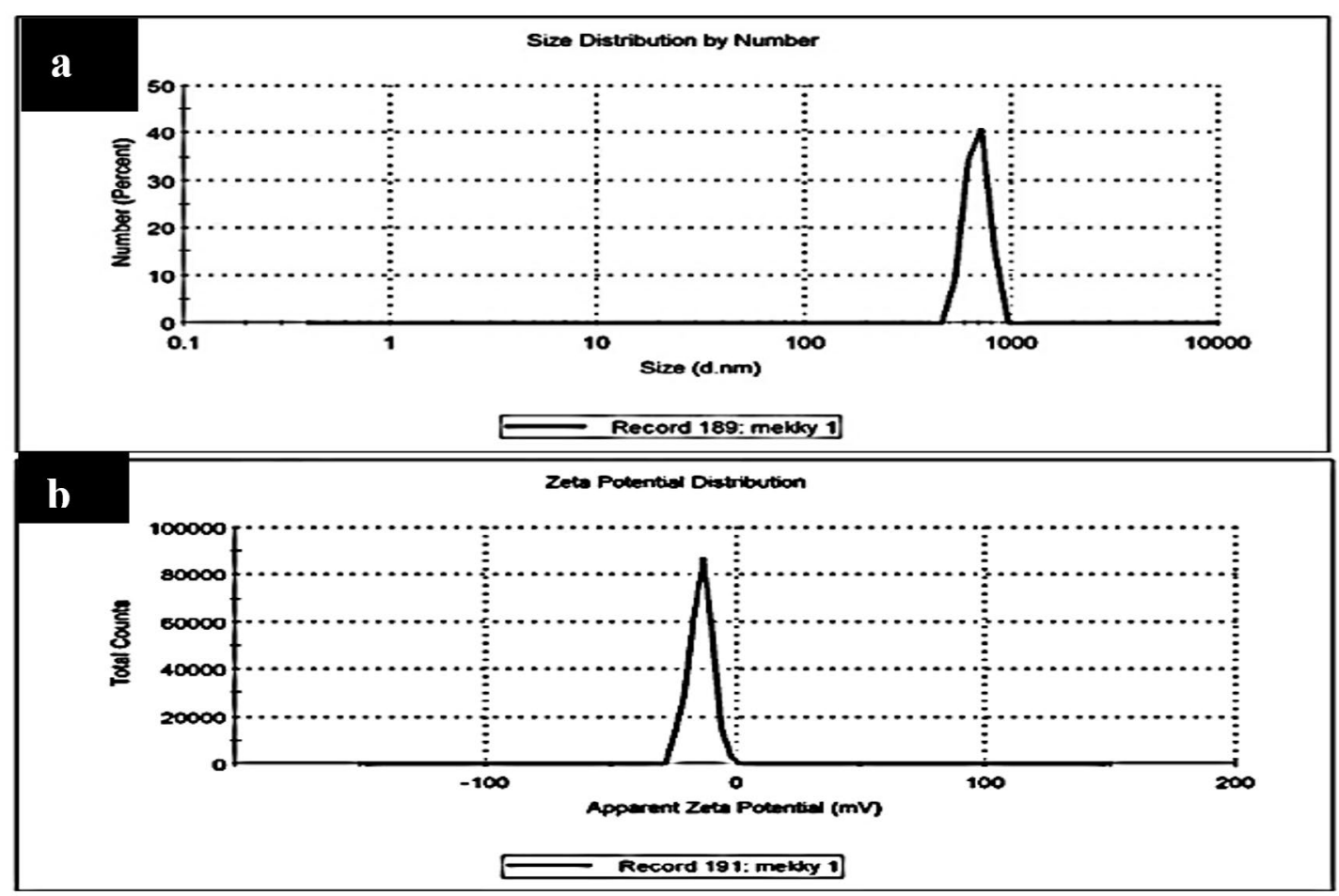

Fig. 7. (a) DLS and (b) Zeta-potential data for green synthesized ZnO NPs using (A. niger) extracellular extract. 
effect of biomolecules present in the water extract of $A$. niger.

Finally, FT-IR analysis was performed to determine the probable interactions between $\mathrm{ZnO}$ and biologically active molecules, which might be the reason for the composition and stabilization (end-capping) of ZnO NPs (Fig. 8). Peaks Strong $3463,2343,1637,1384,1255$ and $526 \mathrm{~cm}^{-1}$, respectively, indicate the presence of hydroxyl groups $(\mathrm{OH})$, benzene rings, carboxyl groups ( $\mathrm{C}$ $=0)$, and halogenated alkyl groups. FT-IR results are used to identify potential biomolecules for ZnO-NPs. The significant peaks of the FT-IR results exhibit the conformable values of the amide group ( $\mathrm{NH}$ stretched $3428 \mathrm{~cm}^{-1}$ ), the alkene (CC$1637,1384,1255$, and $\left.526 \mathrm{~cm}^{-1}\right)$, and the ether group (COC-1043, $3 \mathrm{~cm}^{-1}$ ). Similar observations have been found in flavonoids, triterpenes, and polyphenols ${ }^{63}$.

Therefore, terpenoids have been shown to have perfect potency to transform aldehyde groups on metal ions into carboxylic acids.

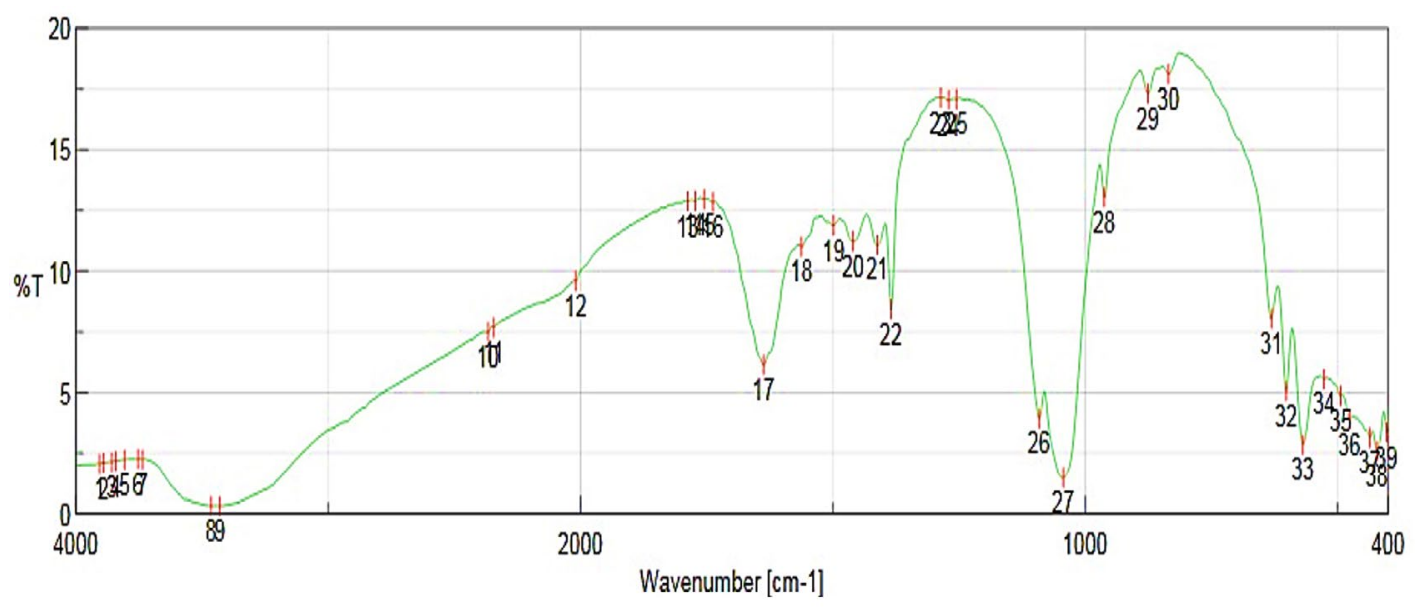

Fig. 8. FT-IR spectra for green synthesized ZnO NPs using $A$. niger extracellular extract.

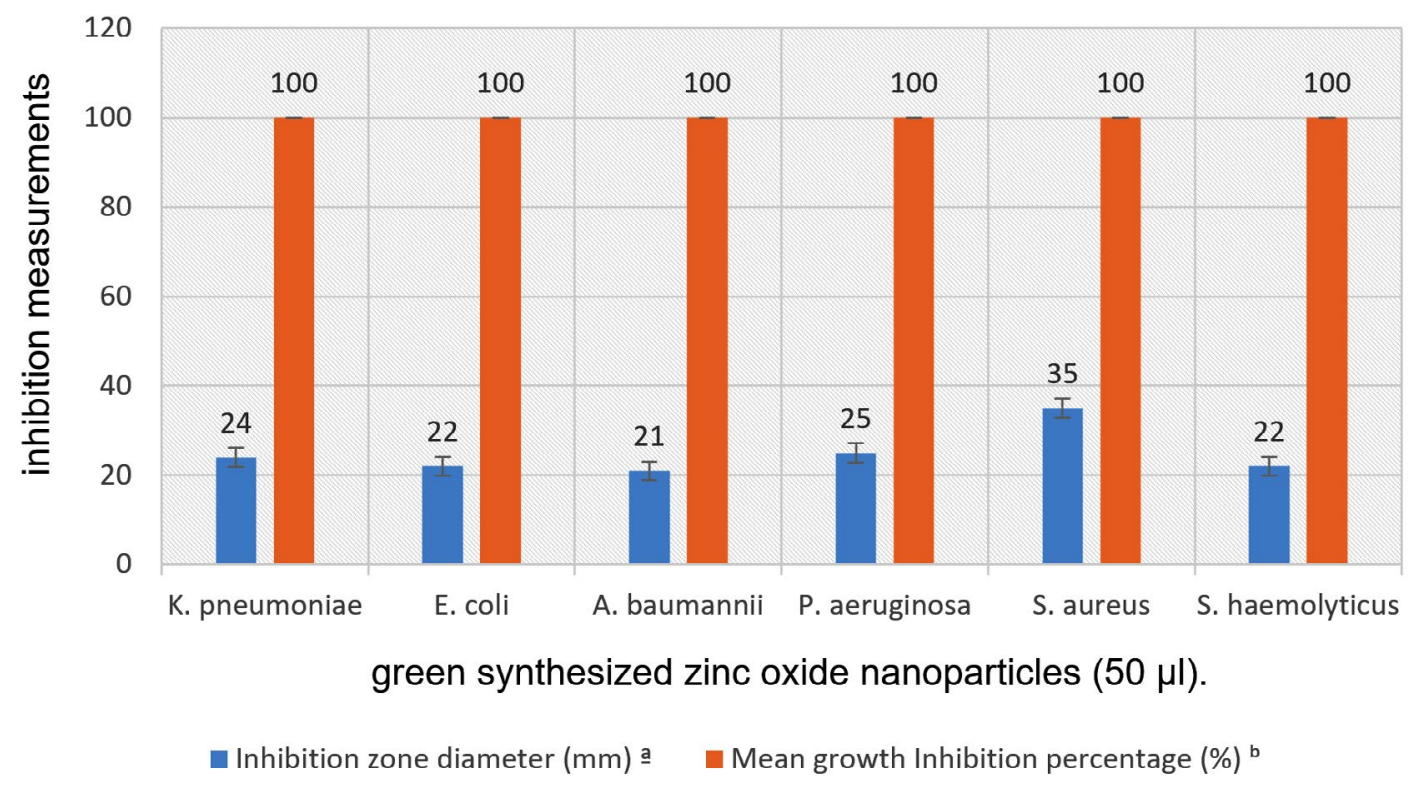

Fig. 9. Antibacterial activity of ZnONPs against the tested bacterial strains diameter of inhibition zone and mean growth inhibition percentage. 
Table 3. The antibacterial activity of prepared ZnO-NPs using agar well diffusion method and broth micro dilution assay.

\begin{tabular}{lcc}
\hline Bacterial Isolates & \multicolumn{2}{c}{ Antibacterial activity } \\
\cline { 2 - 3 } & \begin{tabular}{c} 
Synthesized ZnONPs nanoparticles $(50 \mu \mathrm{L})$ \\
\cline { 2 - 3 }
\end{tabular} & $\begin{array}{c}\text { Dean growth Inhibition } \\
\text { zone }(\mathrm{mm}) \text { a }\end{array}$ \\
\hline K. pneumoniae & $24 \pm 0.75$ & $100 \pm 0.00$ \\
E. coli & $22 \pm 0.55$ & $100 \pm 0.22$ \\
A. baumannii & $21 \pm 0.64$ & $100 \pm 0.44$ \\
P. aeruginosa & $25 \pm 0.82$ & $100 \pm 0.42$ \\
S. aureus & $35 \pm 0.42$ & $100 \pm 0.26$ \\
S. haemolyticus & $22 \pm 0.61$ & $100 \pm 0.22$ \\
\hline
\end{tabular}

a) Diameter of Inhibition zone including the well diameter of $6 \mathrm{~mm}$ was determined by the agar well diffusion method.

b) Mean growth inhibition percentage (\%) was determined by the broth micro dilution method.

Furthermore, the amide group is also responsible for the presence of enzymes, which are responsible for the reductive synthesis and establishment of metal ions. Furthermore, polyphenols have also been shown to be potential reducing agents in the synthesis of NP from $\mathrm{ZnO}^{64,65}$.

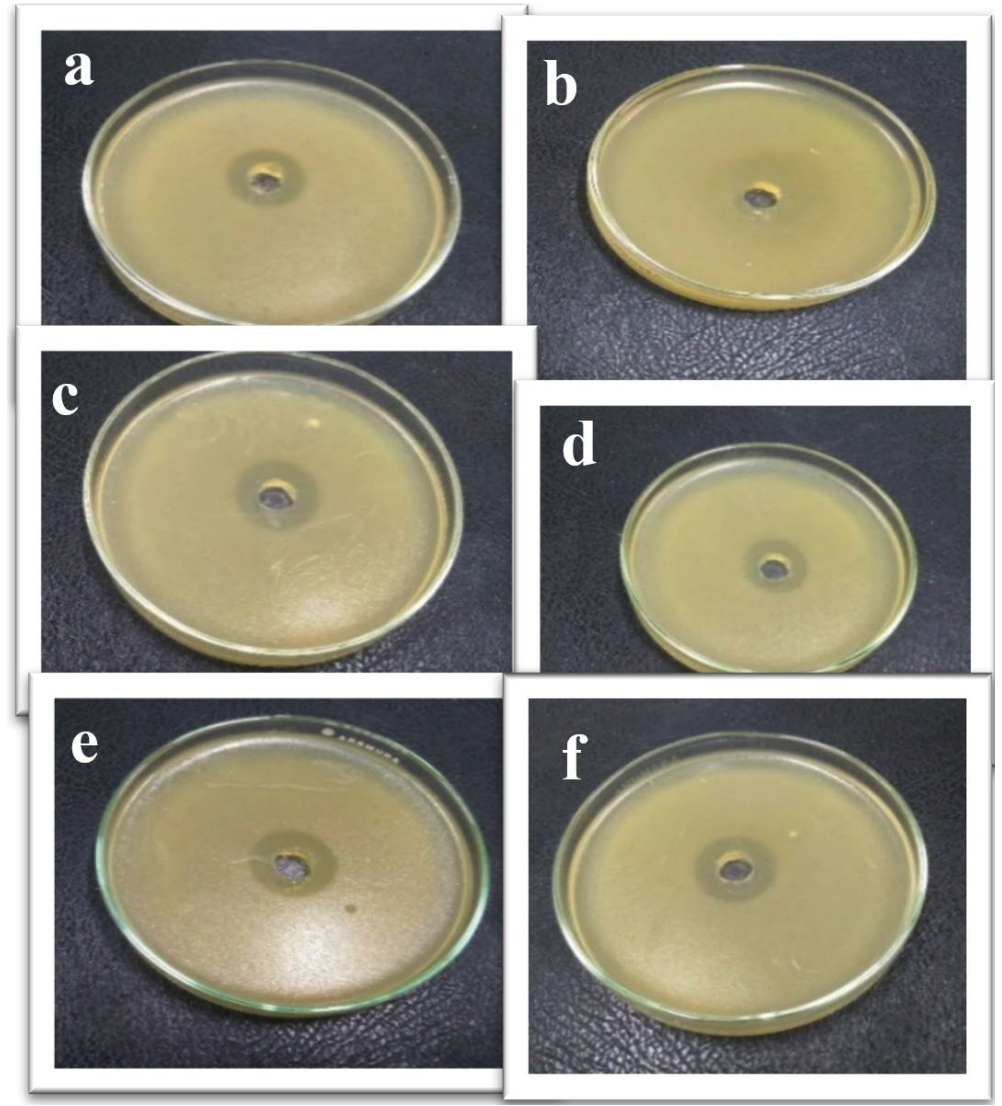

Fig. 10. Inhibition zones produced against tested bacterial isolates (a) K. pneumoniae, (b) E. coli, (c) A. baumannii, (d) P. aeruginosa, (e) S. aureus and (f) S. haemolyticus using green synthesized zinc oxide nanoparticles. 
Table 4. The antifungal activity of prepared ZnO-NPs using agar well diffusion method and broth micro dilution assay

\begin{tabular}{lcc}
\hline Fungal Isolates & \multicolumn{2}{c}{ Antifungal activity } \\
\cline { 2 - 3 } & \begin{tabular}{c} 
Synthesized ZnO-NPs nanoparticles $(50 \mu \mathrm{L})$ \\
\cline { 2 - 3 }
\end{tabular} \\
\hline A. niger & $35 \pm 0.55$ & $\begin{array}{c}\text { Mean growth Inhibition } \\
\text { percentage }(\%)^{\text {b }}\end{array}$ \\
P. marneffie & $31 \pm 0.24$ & $100 \pm 0.22$ \\
C. glabrata & $20 \pm 0.43$ & $100 \pm 0.31$ \\
C. parapsilosis & $18 \pm 0.41$ & $100 \pm 0.22$ \\
\end{tabular}

a) Diameter of Inhibition zone including the well diameter of $6 \mathrm{~mm}$ was determined by the agar well diffusion method.

b) Mean growth inhibition percentage (\%) was determined by the broth micro dilution assay.

Table 5. Minimum inhibitory concentration (MIC) against bacterial strains

\begin{tabular}{lc}
\hline $\begin{array}{l}\text { Bacterial } \\
\text { Strains }\end{array}$ & $\begin{array}{c}\text { MICs of ZnO } \\
\text { nanoparticles }(\mu \mathrm{g} / \mathrm{ml})\end{array}$ \\
\hline K. pneumoniae & 50 \\
$\begin{array}{l}\text { E. coli } \\
\text { A. baumannii }\end{array}$ & 12.5 \\
P. aeruginosa & 12.5 \\
S. aureus & 50 \\
S. haemolyticus & 12.5 \\
\hline
\end{tabular}

\section{Antimicrobial property (antibacterial and antifungal activity)}

The biggest healthy risk in every place in the world nowadays is antimicrobial impedance, which damages the health of humans and raises the risk of diseases and death-rate linked to serious life- menacing diseases. Therefore, scientists from many different domains are examining the antibacterial effects of plants on multi-drug resistant bacteria in a new way ${ }^{66}$. The antimicrobial property, including the antibacterial action of green synthesized ZnO- NPs against bacterial strains, has been determined for $K$. pneumoniae, E. coli, A. baumannii, P. aeruginosa, S. aureus, and $S$. haemolyticus as bacterial isolates. In addition, the antifungal activity of $A$. niger, $P$. marneffei, C. glabrata, and Candida parapsilosis as fungal isolates using well diffusion agar prescribed by other authors ${ }^{67}$. The experiment was completed

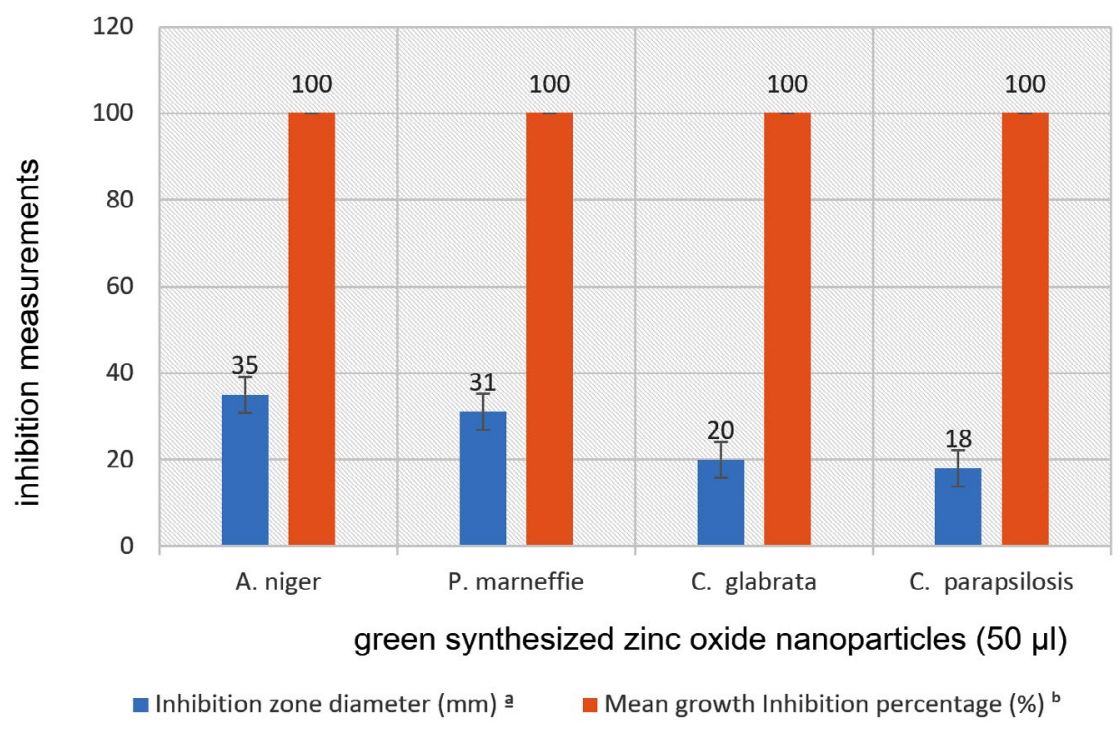

Fig. 11. Anti-fungal activity of ZnONPs against the tested fungal strains diameter of inhibition zone and mean growth inhibition percentage 
in triplicate and the data is exhibited in the form of mean $\pm \mathrm{SE}$.

Based on the observed results, ZnO-NP synthesized via $A$. niger watery extract was an active antibacterial substance for Gram negative and Gram-positive bacteria. In such cases, the diameter of the inhibitory area (left) is about 24, 22, 21, 25, 35 and $22 \mathrm{~mm}$. In addition Mean growth inhibition percentage was about 100 for all bacterial strains (Table 3 and Fig. 9, 10), for $K$. pneumoniae, E. coli, A. baumannii, P. aeruginosa, S. aureus, and $S$. haemolyticus. These results
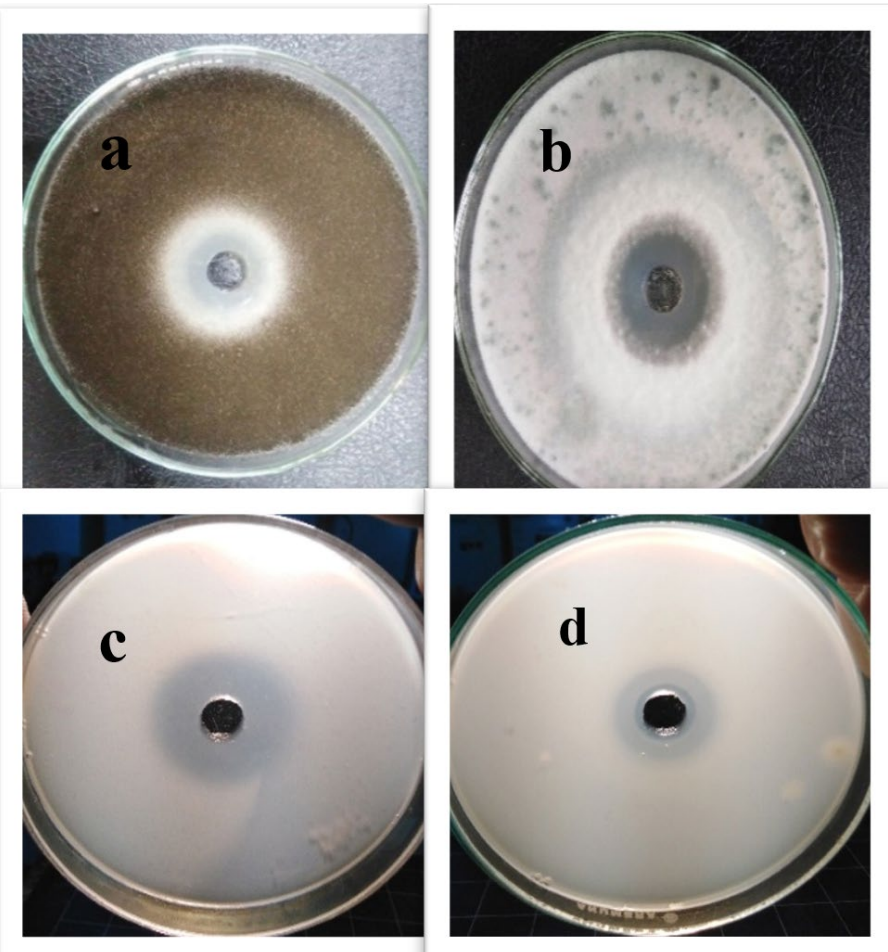

Fig. 12. Inhibition zones produced against (a) A. niger, (b) P. marneffie, (c) C.glabrata and (d) C. parapsilosis using as-prepared zinc oxide nanoparticles.

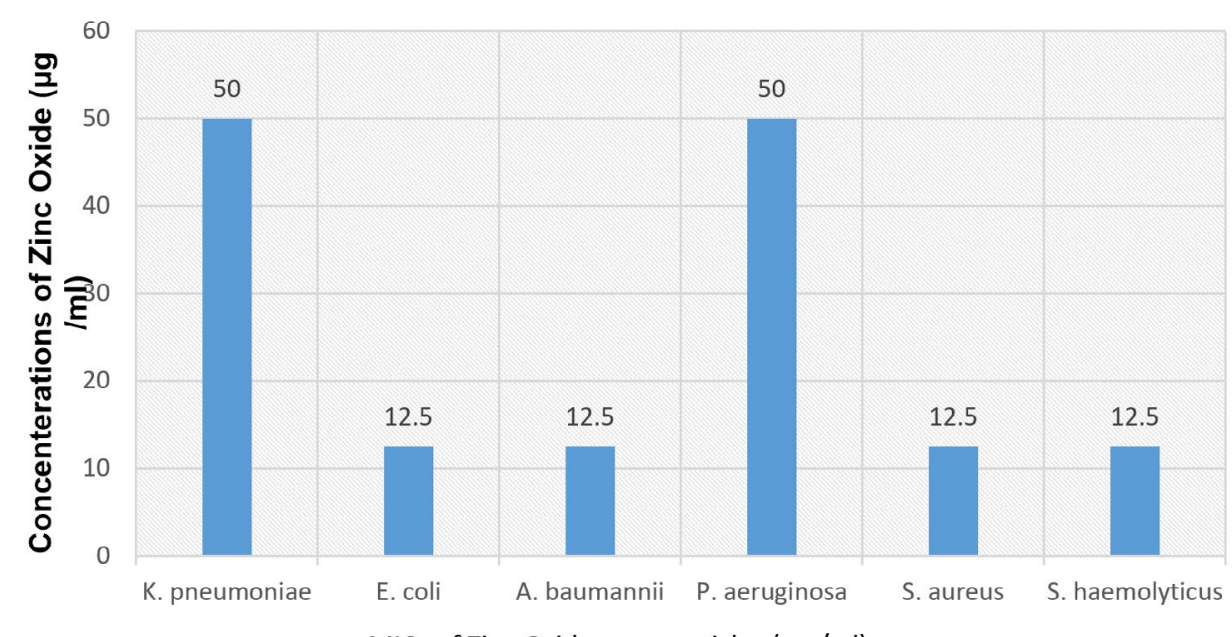

MICs of Zinc Oxide nanoparticles ( $\mu \mathrm{g} / \mathrm{ml})$

Fig. 13. Minimum inhibitory concentrations (MICs) histogram against the pathogenic bacterial strains. 
were consistent with the results informed by Jan et al. ${ }^{68}$. In addition, Klebsiella Pneumoniae is a dangerous opportunistic pathogen that is involved in many serious human diseases and is considered to be an important dietary source that is found in many types of food ${ }^{69}$. Jan and colleagues reported that the antimicrobial effect of ZNO-NPS is more effective against the yellow conveyor than against pseudomonas aeruginosa.

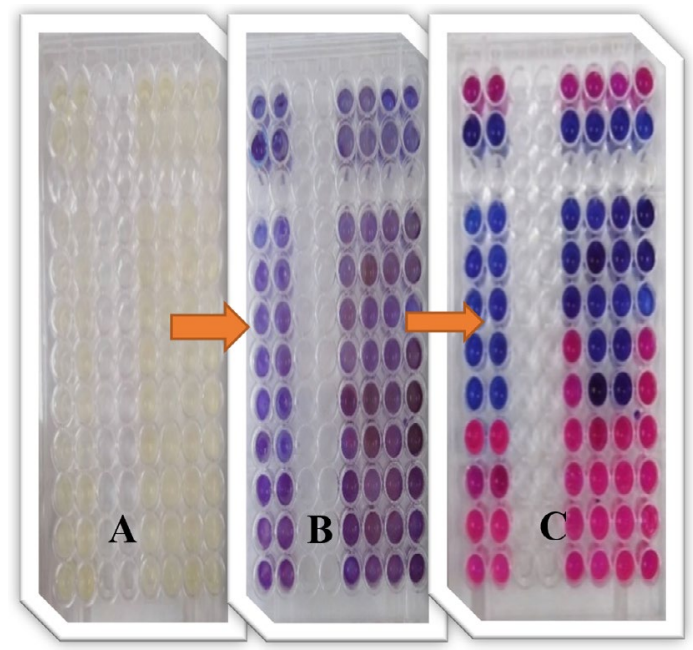

Fig. 14. Ninety-six well Microtiter plates of the colorimetric-XTT assay for determination of MICs values of $\mathrm{ZnO}$ NPs against bacterial strains using resazurin salt, (A) cart preparation, (B) after addition resazurin dye and (C) the results after incubation.
Table 6. Minimum inhibitory concentration (MIC) against fungal isolates

\begin{tabular}{lc}
$\begin{array}{l}\text { Fungal } \\
\text { Isolates }\end{array}$ & $\begin{array}{c}\text { MICs of Silver } \\
\text { nanoparticles }(\mu \mathrm{g} / \mathrm{ml})\end{array}$ \\
\hline $\begin{array}{l}\text { A. niger } \\
\text { P. marneffie }\end{array}$ & 25 \\
C. glabrata & 12.5 \\
C. parapsilosis & 12.5 \\
\hline
\end{tabular}

Other studies developed by ZnO Spherical nanoparticles by biosynthesis of ZnO-NPs via Catharanthus roseus were in the range of 23$57 \mathrm{~nm}$, and we revealed excellent antibacterial activity against $S$. aureus, $B$. thuringiensis, and $E$. coli Green injury ${ }^{70}$. Not only for bacteria; Sofy et al. reported that spraying Tomato plants with ZnONPs Tomv (100 mg / I ZnO-NPs) and to overcome the HVV infection by inducing antioxidant defence systems, it was reported that it is the desired strategy ${ }^{71}$. Other researchers have successfully prepared new salicylidene-iminothiazole and benzylidene-bis-iminothiazole bases to explore their antibacterial and antifungal performance ${ }^{72}$. Because manufactured antibacterial have a negative effect on food quality, and human health, so natural antibacterial are urgently required ${ }^{73}$.

Regarding the antifungal activity of asprepared ZnO NPs against $A$. niger, P. marneffie, C. glabrata, and C. parapsilosis as tested fungal isolates have been investigated using the method

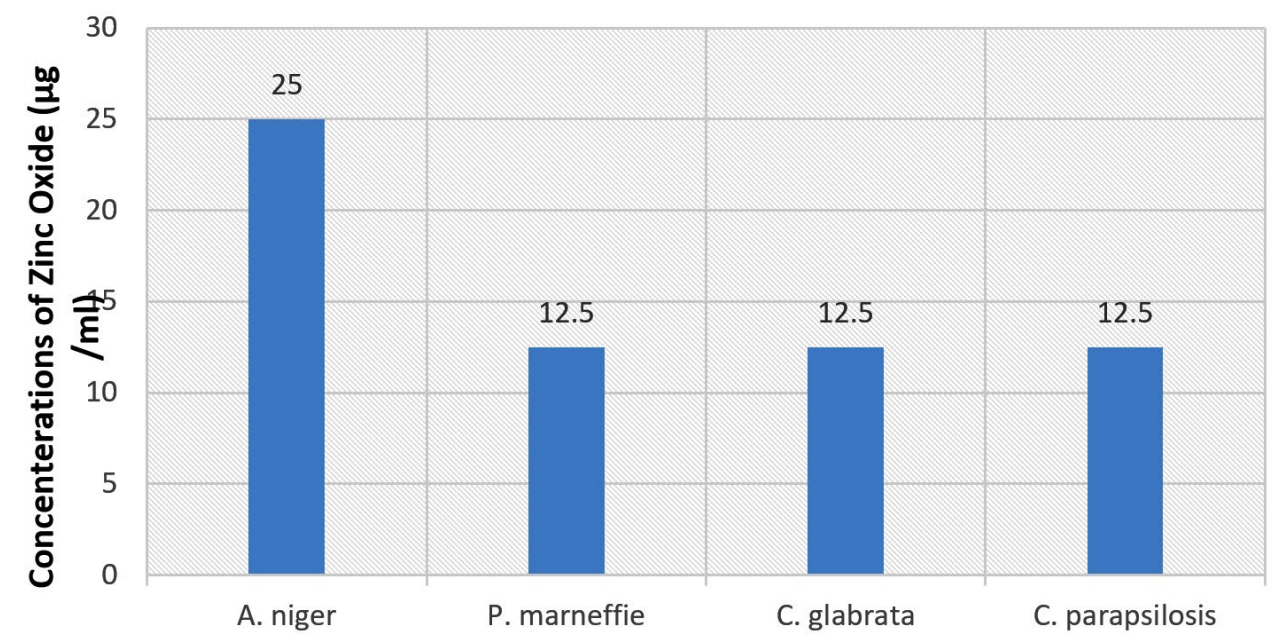

MICs of Zinc Oxide nanoparticles ( $\mu \mathrm{g} / \mathrm{ml})$

Fig. 15. Minimum inhibitory concentration (MIC) histogram against the pathogenic fungal strains. 
of agar well diffusion. The results in Table 4 and Fig. 11,12 showed that $A$. niger is more susceptible to ZnO NPs than other fungal isolates with an inhibition zone of about $35 \mathrm{~mm}$ at an appropriate volume of $50 \mu$ l of as-prepared ZnO NPs solution.

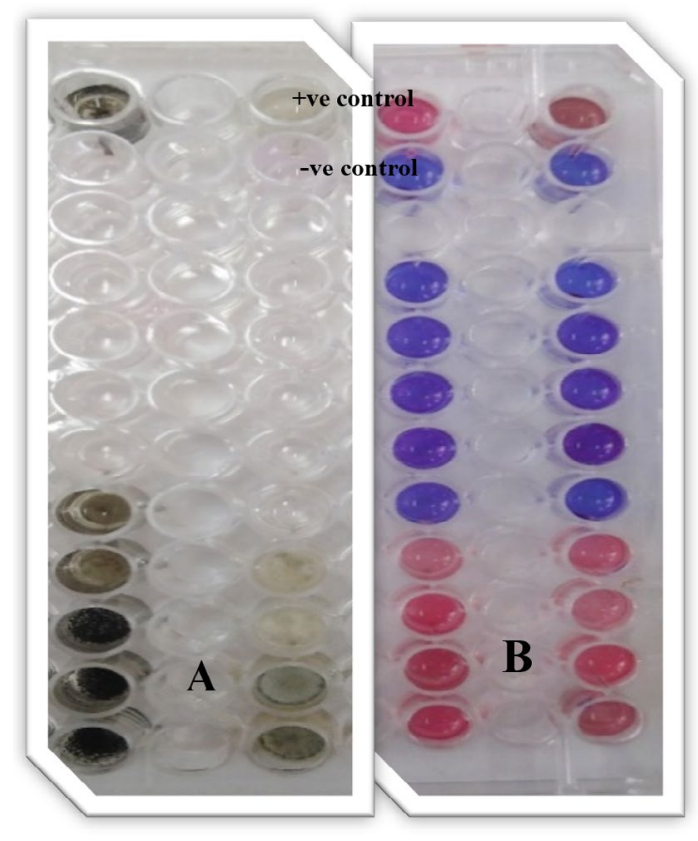

Fig. 16. Ninety-six well Microtiter plates of the colorimetric-XTT assay for determination of MIC values of $\mathrm{ZnO}$ NPs against fungal isolates. A: multi cellular fungi (1- A. niger and 2- P. marneffie), B: unicellular fungi (3C. glabrata and 4- C. parapsilosis using resazurin salt).
Whereas, the inhibition zone diameters (IZD) for other fungal isolates were about 31, 20 and $18 \mathrm{~mm}$ for P. marneffie, C. glabrata, and C. parapsilosis respectively. In addition, the mean growth inhibition percentage was about 100 for all fungal isolates. Also, ZnO-NPs may have antiviral activity against several types of viruses such as Cucumovirus and tobamovirus, and treat many of viral diseases such as Fruit Tree Viroid Diseases, Citrus Gummy Bark Disease and Potato Spindle Tuber Viroid ${ }^{74-78}$. Other researchers successfully prepared a new compound called polyquaternary phosphonium oligochitosans (PQPOCs) to be used as a natural synergistically bio reductant compound to reduce silver $\left(\mathrm{Ag}^{+}\right)$ions into silver nanoparticles and as a stabilizing factor for these silver nanoparticles to manufacture PQPOCsAgNPs Nano-biocompunds for use as an antiviral ${ }^{79}$. The experiment was completed in triplicate and the data is exhibited in the form of mean $\pm \mathrm{SE}$.

Determination of minimum inhibitory concentrations (MICs)

The minimum inhibitory concentrations (MICs) values of $\mathrm{ZnO}$ NPs against the bacterial strains ranged from $12.5 \mu \mathrm{g} / \mathrm{ml}$ to $50 \mu \mathrm{g} / \mathrm{ml}$ (Table 5). E. coli, A. baumannii, S. aureus and S. haemolyticus showed an MIC of $12.5 \mu \mathrm{g} / \mathrm{mL}$. While $K$. pneumoiae and P. aeruginosa showed an MIC of $50 \mu \mathrm{g} / \mathrm{ml}$.

Resazurin tincture was used in this study as an indicator to determine microbial cell

\section{toxicity effect of Zn NPs on wi38 cells at different concentration} $\%$

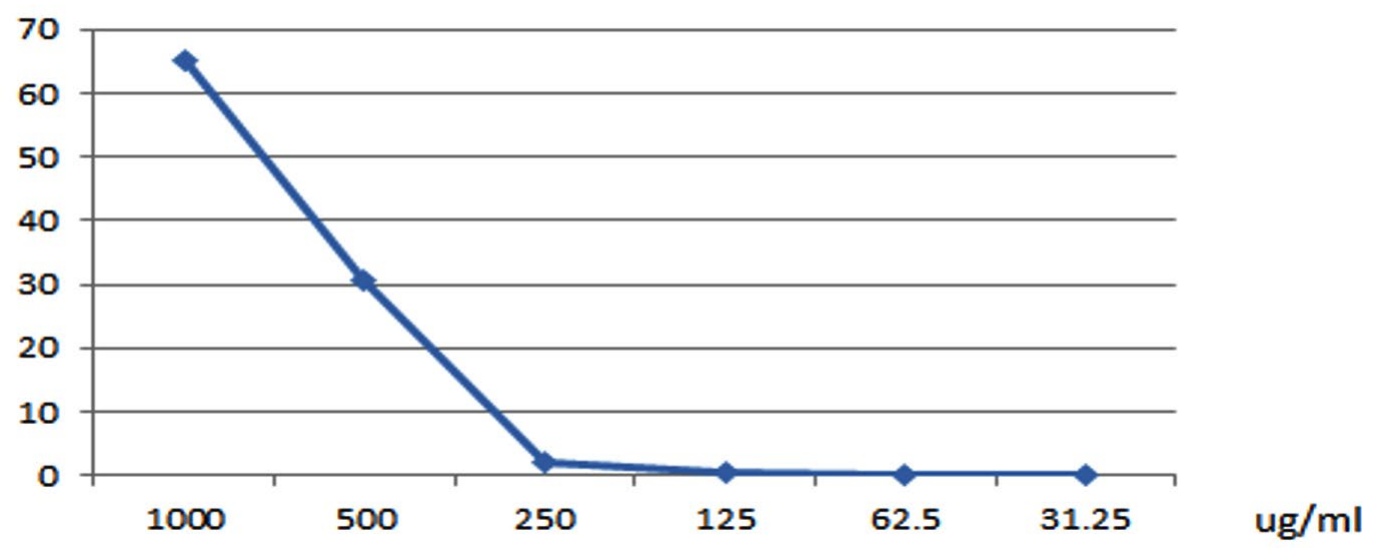

Fig. 17. Effect of ZnONP on wi38 cells at different concentrations. 
Table 7. Effect of ZnONPs on wi38 cells at different concentrations

\begin{tabular}{lccccccccc}
\hline ID & $\begin{array}{c}\text { Conc. } \\
\text { ug/ml }\end{array}$ & & O.D & & $\begin{array}{c}\text { Mean } \\
\text { O.D }\end{array}$ & ST.E & $\begin{array}{c}\text { Viability } \\
\%\end{array}$ & $\begin{array}{c}\text { Toxicity } \\
\%\end{array}$ & IC $_{50}$ \\
\hline Wi38 & $1: 2$ & 0.362 & 0.358 & 0.378 & 0.366 & 0.00611 & 100 & 0 & ----- \\
& 1000 & 0.14 & 0.125 & 0.116 & 0.127 & 0.007 & 34.69945355 & 65.30054645 & \\
& 500 & 0.268 & 0.251 & 0.243 & 0.254 & 0.007371 & 69.3989071 & 30.6010929 & \\
ZnONPs & 250 & 0.348 & 0.375 & 0.352 & 0.358333 & 0.008413 & 97.90528233 & 2.094717668 & 800.42 \\
& 125 & 0.368 & 0.36 & 0.364 & 0.364 & 0.002309 & 99.45355191 & 0.546448087 & \\
& 62.5 & 0.373 & 0.365 & 0.362 & 0.366667 & 0.003283 & 100.1821494 & 0 & \\
& 31.25 & 0.377 & 0.359 & 0.363 & 0.366333 & 0.005457 & 100.0910747 & 0 & \\
\hline
\end{tabular}

Wi-38: human cell strain used. O.D: mean optical density.

ST.E: Standard Divisions Error. IC50: half maximal inhibitory concentration.
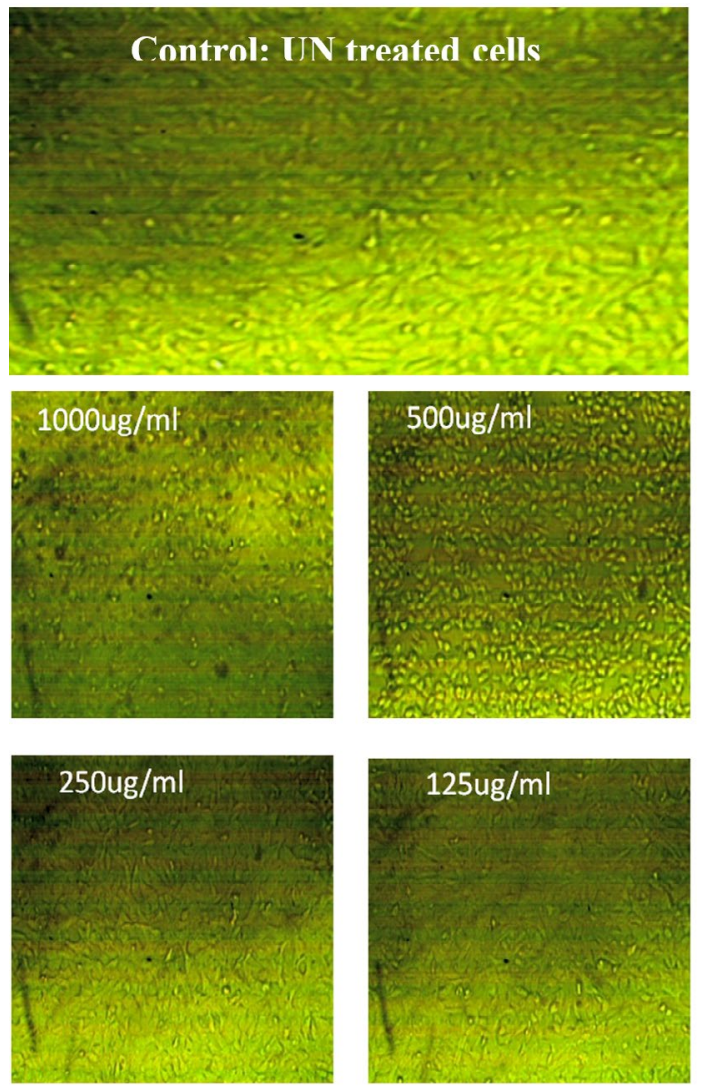

Fig. 18. Effect of ZnONPS on wi38 cells (Homo sapiens, lung, fibroblast, adherent and normal) at different concentrations.

growth $^{81}$. The oxidoreductases enzyme inside living microbial cells reduces the resazurin salt to resorufin and changes the blue non-fluorescent colour of resazurin salt to pink and the fluorescent colour of resorufin (Fig. 13, 14).

While the determination of MIC for $\mathrm{ZnO}$ NPs against fungal isolates have been depicted in Table 6 and Fig. 15, 16. The potential antifungal activity of ZnO NPs on A. niger, P. marneffie, $C$. parapsilosis, and C. glabrata was assured by MICs experimentation. The minimum inhibitory concentrations of zinc oxide nanoparticles on $P$. marneffie, C. parapsilosis, C. glabrata tested were $12.5 \mu \mathrm{g} / \mathrm{ml}$. The MIC on $A$. niger was higher than other tested species, about $25 \mu \mathrm{g} / \mathrm{ml}$.

\section{Cytotoxicity assay}

Viability screening is fundamental for evaluation of the cellular response to toxic materials. To determine total cell viability after nanoparticles exposure, we used the MTT method described by Riss and Moravec ${ }^{53}$. Zinc oxide nanoparticles, because of their physical and chemical characteristics, are considered an effective material in cancer therapy ${ }^{81}$.

New biosynthetic methods of ZnO-NP use natural environmental sources such as water extracts of plants and fungi that reduce metal ions compared with physical methods and chemicals, they are easy to apply and non-toxic ${ }^{82}$.

The cytotoxic mechanism of ZnO-NP is not fully understood, but it is believed that the major components of hydroxyl radicals $\left(\mathrm{OH}^{*}\right)$, superoxide anions $\left(\mathrm{O}_{2}{ }^{-}\right)$, and per-hydroxyl radicals $\left(\mathrm{HO}_{2}{ }^{*}\right)$ are generated from the surface of $\mathrm{ZnO}$ NP. When interaction occurs between cells and nanoparticles, cellular preservation mechanisms at this time are activated to decrease damage. 
However, if the highly active free radical production exceeds the anti-oxidative defensive ability of the cell, it results in oxidative harm of biomolecules which can lead to cell death ${ }^{33,84}$.

Treatment with natural-synthetic ZnO-NP resulted in significant changes in cell morphology at 1000 and $500 \mu \mathrm{g} / \mathrm{ml}$ concentrations. Therefore, a microscopic examination was performed. As shown in Table 7 and Figure 17 \& 18, the control cells remained normal. These results show high cytotoxicity values at high concentrations of ZnO-NP, as reported by Brunner et al., using lower concentrations and similar particle sizes in chemically prepared ZnO-NPs. However, they also reported significantly less cytotoxicity (with a particle size larger or smaller than this study) using the same concentration and cell line ${ }^{83}$.

After treatment of cells with lower concentrations of ZnO-NPs in Figure 17 \& 18, and Table 7. The Cells ' morphology was not different from that of the control, and most of the cells could adhere and spread.

\section{CONCLUSION}

The current study shows that zinc oxide ( $\mathrm{ZnO})$ nanoparticles have been successfully biosynthesized using fungi as a biological system can be done easily. Aspergillus niger can be operated under controlled conditions and has great potential for synthesizing metal oxide nanoparticles outside and inside the cell. The synthesized nanoparticles are stabilized by the protein released by the fungus during the synthesis of NP from outside the $\mathrm{ZnO}$ cell. Through different characterization techniques, such as ultravioletvisible light absorption, morphological structure using TEM and XRD, the physical characteristics of the prepared zinc oxide $(\mathrm{ZnO})$ nanoparticles were studied. Then, the colloidal stability uses zeta meter technology and the surface function uses FT-IR spectroscopy. The average particle size is approximately $20 \pm 5 \mathrm{~nm}$ and it has a hexagonal structure. Furthermore, the prepared particles show significant antimicrobial activity against different bacterial and fungal isolates. They exhibited different levels of cytotoxicity dependent upon the concentration of ZnO NPs using the MTT assay with an $\mathrm{IC}_{50}{ }^{2} 800.42$.

\section{ACKNOWLEDGMENTS}

None.

\section{CONFLICT OF INTEREST}

The authors declare that there is no conflict of interest.

\section{AUTHORS' CONTRIBUTION}

All authors listed have made a substantial, direct, and intellectual contribution to the work, and approved it for publication.

\section{FUNDING}

None.

\section{DATA AVAILABILITY}

All data included in this study were presented in the form of tables and Figures.

\section{ETHICS STATEMENT}

The protocol of this study was approved by the Faculty of Science, Al-Azhar University, Cairo, Egypt (2018).

\section{REFERENCES}

1. Mohamed AA, Abu-Elghait M, Ahmed NE, Salme SS. Eco-friendly Mycogenic Synthesis of ZnO and CuO Nanoparticles for In Vitro Antibacterial, Antibiofilm, and Antifungal Applications. Biol Trace Elem Res. 2021;199(7):2788-2799. doi: 10.1007/s12011-02002369-4

2. Abu-Elghait $M$, Hasanin $M$, Hashem AH, Salem SS. Ecofriendly novel synthesis of tertiary composite based on cellulose and myco-synthesized selenium nanoparticles: Characterization, antibiofilm and biocompatibility. Int J Biol Macromol. 2021;175:294303. doi: 10.1016/j.ijbiomac.2021.02.040

3. TI Shaheen, SS Salem, A Fouda. Current Advances in Fungal Nanobiotechnology: Mycofabrication and Applications. In: Lateef A., Gueguim-Kana E.B., Dasgupta N., Ranjan S. (eds) Microbial Nanobiotechnology. Materials Horizons: From Nature to Nanomaterials. Springer, Singapore. 2021. doi.org/10.1007/978-981-33-4777-9_4

4. Mohamed AA, Fouda A, Abdel-Rahman MA, et al. Fungal strain impacts the shape, bioactivity and multifunctional properties of green synthesized zinc oxide nanoparticles. Biocatalysis and Agricultural Biotechnology. 2019;19:101103. doi: 10.1016/j. bcab.2019.101103

5. Salem SS, Fouda A. Green Synthesis of Metallic Nanoparticles and Their Prospective Biotechnological Applications: an Overview. Biol Trace Elem Res. 2021;199(1):344-370. doi: 10.1007/s12011-02002138-3 
6. Hashem AH, Khalil AMA, Reyad AM, Salem SS. Biomedical Applications of Mycosynthesized Selenium Nanoparticles Using Penicillium expansum ATTC 36200. Biol Trace Elem Res. 2021. doi: 10.1007/s12011020-02506-z

7. Aref MS, Salem SS. Bio-callus synthesis of silver nanoparticles, characterization, and antibacterial activities via Cinnamomum camphora callus culture. Biocatalysis and Agricultural Biotechnology. 2020;27:101689. doi: 10.1016/j.bcab.2020.101689

8. Li XQ, Xu HZ, Chen ZS, Chen GF. Biosynthesis of nanoparticles by microorganisms and their applications. Journal of Nanomaterials. 2011;2011:270974. doi: $10.1155 / 2011 / 270974$

9. Shaheen $\mathrm{TI}$, Fouda A, Salem SS. Integration of Cotton Fabrics with Biosynthesized CuO Nanoparticles for Bactericidal Activity in the Terms of Their Cytotoxicity Assessment. Industrial and Engineering Chemistry Research. 2021;60(4):1553-1563. doi: 10.1021/acs. iecr.0c04880

10. Salem SS, Fouda MMG, Fouda A, et al. Antibacterial, Cytotoxicity and Larvicidal Activity of Green Synthesized Selenium Nanoparticles Using Penicillium corylophilum. Journal of Cluster Science. 2021;32(2):351-361. doi: 10.1007/s10876-020-017948

11. Kolodziejczak-Radzimska A, Jesionovski T. Zinc oxide - From synthesis to application: A review. Materials. 2014;7(4):2833-2881. doi: 10.3390/ma7042833

12. Fouda A, Saad EL, Salem SS, Shaheen TI. InVitro cytotoxicity, antibacterial, and UV protection properties of the biosynthesized Zinc oxide nanoparticles for medical textile applications. Microbial pathogenesis. 2018;125:252-261. doi: 10.1016/j.micpath.2018.09.030

13. Shaheen TI, Salem SS, Zaghloul S. A New Facile Strategy for Multifunctional Textiles Development through In Situ Deposition of $\mathrm{SiO}_{2} / \mathrm{TiO}_{2}$ Nanosols Hybrid. Ind EngChem Res. 2019;58(44):20203-20212. doi: 10.1021/acs.iecr.9b04655

14. Batteza AH, Gonzaleza JR, Viescaa L, et al. CuO, $\mathrm{ZrO}_{2}$ and $\mathrm{ZnO}$ nanoparticles as antiwear additive in oil lubricants. Wear. 2008;265(3-4):422-428. doi: 10.1016/j.wear.2007.11.013

15. Elsawy MM, Faheim AA, Salem SS, Owda ME, Abd ElWahab ZH, Abd El-Wahab H. Cu (II), Zn (II), and Ce (III) metal complexes as antimicrobial pigments for surface coating and flexographic ink. Appl Organomet Chem. 2021;35(5):e6196. doi: 10.1002/aoc.6196

16. Banoee $M$, Seif S, Nazari ZE, et al. ZnO nanoparticles enhanced antibacterial activity of ciprofloxacin against Staphylococcus aureus and Escherichia coli. J Biomed Mater Res. 2010;93B(2):557-561. doi: 10.1002/ jbm.b.31615

17. Liu Y, He L, Mustapha A, Li H, Lin M. Antibacterial activities of zinc oxide nanoparticles against Escherichia coli 0157:H7. J Appl Microbiol. 2009;107(4):11931201. doi: 10.1111/j.1365-2672.2009.04303.x

18. Xie $Y, H e ~ Y$, Irwin PL, Jin T, Shi X. Antibacterial activity and mechanism of action of zinc oxide nanoparticles against Campylobacter jejuni. Appl Environ Microbiol. 2011;77(7):2325-2331. doi: 10.1128/AEM.02149-10
19. Feris K, Otto C, Tinker J, et al. Electrostatic interactions affect nanoparticle mediated toxicity to Gram-negative bacterium Pseudomonas aeruginosa PAO1. Langmuir. 2010;26(6):4429-4436. doi: 10.1021/la903491z

20. Jin T, Gurtler JB. Inactivation of Salmonella in liquid egg albumen by antimicrobial bottle coatings infused with allyl isothiocyanate, nisin and zinc oxide nanoparticles. J App/ Microbiol. 2010;110(3):704-712. doi: 10.1111/j.1365-2672.2011.04938.x

21. Navale GR, Thirpuranthaka M, Late DJ, Shinde SS. Antimicrobial activity of $\mathrm{ZnO}$ nanoparticles against pathogenic bacteria and fungi. JSM Nanotechnol Nanomed. 2015;3:1033.

22. Jones N, Ray B, Ranjit KT, Manna AC. Antibacterial activity of $\mathrm{ZnO}$ nanoparticle suspensions on a broad spectrum of microorganisms. FEMS Microbiology Letters., 2008;279(1):71-76. doi: 10.1111/j.15746968.2007.01012.x

23. Sofy AR, Sofy MR, Hmed AA, et al. Molecular Characterization of the Alfalfa mosaic virus Infecting Solanum melongena in Egypt and the Control of Its Deleterious Effects with Melatonin and Salicylic Acid. Plants. 2021;10(3):459. doi: 10.3390/plants10030459

24. Wahab R, Mishra A, Yun SI, Kim YS, Shin HS. Antibaterial activity of $\mathrm{ZnO}$ nanoparticles prepared via nonhydrolytic solution route. Appl Microbiol Biotechnol. 2010;87(5):1917-1925. doi: 10.1007/s00253-0102692-2

25. Yamamoto O. Influence of particle size on the antibacterial activity of zinc oxide. International Journal of Inorganic Material. 2001;3(7):643-646. doi: 10.1016/S1466-6049(01)00197-0

26. Jalal R, Goharshadi EK, Abareshi M, Moosavi M, Yousefi, A, Nancarrow P. ZnO nanofluids: Green synthesis, characterization, and antibacterial activity. Material Chemistry and Physics. 2010;121(1-2):198-201. doi: 10.1016/j.matchemphys.2010.01.020

27. Arcinegas-grijalba PA, Patino-portela MC, Mosquerasxnchez LP, Guerrerovargas JA, Rodrpguet-pxez JE. $\mathrm{ZnO}$ nanoparticles (ZnO-NPs) and their antifungal activity against coffee fungus Erythricium salmonicolor. Applied Nanoscience. 2017;7(5):225-241. doi: 10.1007/s13204-017-0561-3

28. Narendhran S, Sivaraj R. Biogenic $\mathrm{ZnO}$ nanoparticles synthesized using $L$. aculeate extract and their antifungal activity against plant fungal pathogens. Bulletin of Material Science. 2016;39(1):1-5. doi: 10.1007/s12034-015-1136-0

29. Thakkar KN, Snehit SM, Rasesh YP. Biological synthesis of metallic nanoparticles. Nanomedicine: Nanotechnology, Biology and Medicine. 2010;6(2):257262. doi: 10.1016/j.nano.2009.07.002

30. Pantidos N, Horsfall LE. Biological synthesis of metallic nanoparticles by bacteria, fungi and plants. $J$ Nanomed Nanotechn. 2014;5:2331. doi: 10.4172/21577439.1000233

31. Shah M, Fawcett D, Sharma S, Tripathy S, Poinern G. Green synthesis of metallic nanoparticles via biological entities. Materials. 2015;8(11):7278-7308. doi: 10.3390/ma8115377

32. Yusof HM, Mohamad R, Zaidan UH, Rahman NAA. Microbial synthesis of zinc oxide nanoparticles and 
their potential application as an antimicrobial agent and a feed supplement in animal industry: a review. $J$ Anim Sci Biotechnol. 2019;10:57. doi: 10.1186/s40104019-0368-z

33. Carmody RJ, Cotter TG. Signalling apoptosis: a radicalapproach. Redox Report. 2001;6(2):77-90. doi: $10.1179 / 135100001101536085$

34. Rayter SW, Kim HP, Hoetzel A, et al. Mechanisms of cell deathin oxidative stress. Antioxidants and Redox Signaling. 2007;9(1):49-89. doi: 10.1089/ars.2007.9.49

35. Mueller JH, Hinton J. A protein-free medium for primary isolation of gonococcus and meningococcus. Proc Soc Exp Biol Med. 1941;48:330-333. doi: 10.3181/00379727-48-13311

36. Manual of Microbiological Methods. By the American Society of the Microbiology. Mc Graw Hill Book Co., Inc. New York, Totanto, London. 1957.

37. Barrow GI, Feltham RK. Cowan and steel's Manual for the Identification of Medical Bacteria. 2nd ed. Cambridge Univ. Press. London. 1939.

38. Nucci M, Anaissie EJ. Hyalohyphomycosis. In Clinical mycology. Churchill Livingstone. 2009:309-327. doi: 10.1016/B978-1-4160-5680-5.00013-X

39. Walton JD, Luo $H$, Hallen-Adams H. Ribosomally encoded cyclic peptide toxins from mushrooms. Methods Enzymol. 2012;516:63-77. doi: 10.1016/ B978-0-12-394291-3.00025-3

40. Pitt JI, Hocking AD. In Fungi and food spoilage. New York, Springer. 2009:1-524. doi: 10.1007/978-0-38792207-2_1

41. Qayyum S, Khan I, Maqbool F, Zhao Y, Gu Q, Peng C. Isolation and characterization of heavy metal resistant fungal isolates from industrial soil in China. Pak J Zool. 2016;48(5):1241-1247.

42. Saroj S, Kumar K, Pareek N, Prasad R, Singh RP. Biodegradation of azo dyes Acid Red 183, Direct Blue 15 and Direct Red 75 by the isolate Penicillium oxalicum SAR-3. Chemosphere. 2014;107:240-248. doi: 10.1016/j.chemosphere.2013.12.049

43. Raper KB, Fennell DI. The genus Aspergillus. Williams and Wilkins, 1965:1-686.

44. Diba K, Kordbacheh P, Mirhendi SH, Rezaie S, Mahmoudi M. Identification of Aspergillus species using morphological characteristics. Pak J Med Sci. 2007;23(6):867-872.

45. Zahran MK, Mohamed AA, Mohamed FM, El-Rafie $\mathrm{MH}$. Optimization of biological synthesis of silver nanoparticles by some yeast fungi. Egypt J Chem. 2013;56(1):91-110. doi: 10.21608/ejchem.2013.1078

46. Baskar G, Chandhuru J, Fahad KS, Praveen AS. Mycological synthesis, characterization and antifungal activity of zinc oxide nanoparticles. Asian J Pharm Technol. 2013;3(4):142-146.

47. Vivek M, Kumar PS, Steffi S, Sudha S. Biogenic Silver Nanoparticles by Gelidiella acerosa Extract and their Antifungal Effects. Avicenna J Med Biotechnol. 2011;3:143-148.

48. Bergey's Manual. Bergey's manual of systematic bacteriology. Sneath PHA,Shar M, Elizabeth, Holt JG (Eds.) Pub. Williams and Wilkins. 2009;26:1-5.

49. Perez C, Pauli M, Bazerque P. An antibiotic assay by agar-well diffusion method. Acta Biologiae Medecine
Experimentaalis. 1990;15:113-115.

50. Clinical and Laboratory Standards Institude. Performance standards for antimicrobial disk susceptibility tests; approved standard-tenth edn 29: M02-A10. National Committee for Clinical Laboratory Standards 29.2009.

51. Khalifa RA, Nasser MS, Gomaa AA, Osman NM, Salem HM. Resazurin Microtiter Assay Plate method for detection of susceptibility of multidrug resistant Mycobacterium tuberculosis to second-line anti-tuberculous drugs. Egypt J Chest Dis Tuberc. 2013;62(2):241-247. doi: 10.1016/j.ejcdt.2013.05.008

52. National Committee for Clinical Laboratory Standards. Reference method for broth dilution antifungal susceptibility testing of conidium-forming filamentous fungi. Proposed standard M38-P. National Committee for Clinical Laboratory Standards Wayne, Pa. 1999.

53. Riss L, Moravec A. Use of multipic assay endpoints to investigate the effects of incubation time, dose of toxin, and plating density in cell-based cytotoxicity assays. Assay Drug Dev Technol. 2004;2(1):51-62. doi: 10.1089/154065804322966315

54. Kareem SH, Naji AM, Taqi ZJ, Jabir MS. Polyvinylpyrrolidone Loaded-MnZnFe 204 Magnetic Nanocomposites Induce Apoptosis in Cancer Cells Through Mitochondrial Damage and P 53 Pathway. Journal of Inorganic and Organometallic Polymers and Materials. 2020;30(12):5009-5023. doi: 10.1007/ s10904-020-01651-1

55. Jain N, Bhargava A, Tarafdar JC, Singh SK, Panwar J. A biomimetic approach towards synthesis of zinc oxide nanoparticles. Appl Microbiol Biotechnol. 2013;97(2):859-869. doi: 10.1007/s00253-012-3934-2

56. Rajan A, Cherian E, Baskar G. Biosynthesis of zinc oxide nanoparticles using Aspergillus fumigatus JCF and its antibacterial activity. Int J Modern Sci Technol. 2016;1(2):52-57.

57. Kalpana VN, Kataru BAS, Sravani N, Vigneshwari T, Panneerselvam A, Rajeswari VD. Biosynthesis of zinc oxide nanoparticles using culture filtrates of Aspergillus niger: Antimicrobial textiles and dye degradation studies. Open Nano. 2018;3:48-55. doi: 10.1016/j.onano.2018.06.001

58. Ahmed A, Mukherjee P, Senapati S, et al. Extracellular biosynthesis of silver nanoparticles using the fungus Fusarium oxysporum. Colloids Surf Biointerfaces. 2003;28(4):313-318. doi: 10.1016/509277765(02)00174-1

59. Honary S, Barabadi H, Gharaei-Fathabad E, Naghibi F. Green synthesis of silver nanoparticles induced by the fungus Penicillium citrinum. Tropical J Pharm Res. 2013;12(1):7-11. doi: 10.4314/tjpr.v12i1.2

60. Sawada H, Wang R, Sleight AW. An electron density residual study of zinc oxide. Journal of Solid State Chemistry. 1996;122(1):148-150. doi: 10.1006/ jssc.1996.0095

61. Kim KM, Kim TH, Kim HM. Colloidal behaviors of ZnO nanoparticles in various aqueous media. Toxicol Environ Health Sci. 2012;4(2):121-131. doi: 10.1007/ s13530-012-0126-5

62. Kim KM, Choi MH, Lee JK, et al. Physicochemical properties of surface charge-modified ZnO 
nanoparticles with different particle sizes. Int J Nanomedicine. 2014;9(Suppl 2):41-56. doi: 10.2147/ IJN.S57923

63. Nabikhan A, Kandasamy K, Raj A, Alikunhi NM. Synthesis of antimicrobial silver nanoparticles by callus and leaf extracts from saltmarsh plant. Sesuvium portulacastrum L. Colloids. Surf $B$ Biointerfaces. 2010;79(2):488-493. doi: 10.1016/j. colsurfb.2010.05.018

64. Prasad TN, Elumalai EK. Biofabrication of Ag nanoparticles using Moringa oleifera leaf extract and their antimicrobial activity. Asian Pac $J$ TropBiomed. 2011;1(6):439-442. doi: 10.1016/S22211691(11)60096-8

65. Mukunthan KS, Elumalai EK, Patel TN, Murty VR. Catharanthus roseus: a natural source for the synthesis of silver nanoparticles. Asian Pac J TropBiomed. 2011;1(4):270-274. doi: 10.1016/S22211691(11)60041-5

66. Sofy AR, Aboseidah AA, El-Morsi E-S, Azmy HA, Hmed AA. Evaluation of antibacterial and antibiofilm activity of new antimicrobials as an urgent need to counteract stubborn multidrug-resistant bacteria. J Pure App/ Microbiol. 2020;14(1):595-608. doi: 10.22207/ JPAM.14.1.62

67. Balouiri M, Sadiki M, Ibnsouda SK. Methods for in vitro evaluating antimicrobial activity: A review. Journal of Pharmaceutical Analysis. 2016;6(2):71-79. doi: 10.1016/j.jpha.2015.11.005

68. Jan T, Iqbal J, Ismail M, Zakaullah M, Naqvi SH, Badshah $\mathrm{N}$. Sn doping induced enhancement in the activity of $\mathrm{ZnO}$ nanostructures against antibiotic resistant $S$. aureus bacteria. Int J Nanomedicine. 2013;8:36793687. doi: 10.2147/IJN.S45439

69. Sofy AR, El-Dougdoug NK, Refaey EE, Dawoud RA, Hmed AA. Characterization and Full Genome Sequence of Novel KPP-5 Lytic Phage against Klebsiella pneumoniae Responsible for Recalcitrant Infection. Biomedicines. 2021;9(4):342. doi: 10.3390/biomedicines9040342

70. Bhumi G, Savithramma N. Biological synthesis of zinc oxide nanoparticles from Catharanthus roseus $\mathrm{L}$. leaf extract and validation for antibacterial activity. Int $\mathrm{J}$ Drug Delivery Res. 2014;6:208-214.

71. Sofy AR, Sofy MR, Hmed AA, et al. Ameliorating the Adverse Effects of Tomato mosaic tobamovirus Infecting Tomato Plants in Egypt by Boosting Immunity in Tomato Plants Using Zinc Oxide Nanoparticles. Molecules. 2021;26(5):1337. doi: 10.3390/ molecules26051337

72. Elshaarawy RFM, Mustafa FHA, Sofy AR, Hmed $A A$, Janiak $C$. A new synthetic antifouling coatings integrated novel aminothiazole-functionalized ionic liquids motifs with enhanced antibacterial performance. J Environ Chem Eng. 2019;7(1):102800. doi: 10.1016/j.jece.2018.11.044

73. Sofy AR, Mahfouze SA, El-Enany MAM. Isozyme markers for response of wild potato species to Potato spindle tuber viroid egyptian isolate. World App/ Sci J. 2013;27:1010-1022.

74. Megahed AA, El-Dougdoug KhA, Othman BA, Lashin SM, Ibrahim MA, Sofy AR. A New Egyptian Satellite Strain of Cucumber Mosaic Cucumovirus. Int J Virol. 2012;8:240-257. doi: 10.3923/ijv.2012.240.257

75. Sofy AR, Mousa AA, Soliman AM, El-Dougdoug KhA. The Limiting of Climatic Factors and Predicting of Suitable Habitat for Citrus Gummy Bark Disease Occurrence using GIS. Int J Virol. 2012;8(2):165-177. doi: 10.3923/ijv.2012.165.177

76. El-Dougdoug KhA, Dawoud RA, Rezk AA, Sofy AR. Incidence of Fruit Trees Viroid Diseases by Tissue Print Hybridization in Egypt. Int J Virol. 2012;8(1):114-120. doi: 10.3923/ijv.2012.114.120

77. Megahed AA, El- Dougdoug KhA, Othman BA, Lashin SM, Ibrahim MA, Sofy AR. Induction of Resistance in Tomato Plants Against Tomato mosaic tobamovirus Using Beneficial Microbial Isolates. Pak J Biol Sci. 2013;16(8):385-390. doi: 10.3923/pjbs.2013.385.390

78. Sofy AR, Abd El Haliem NF, Refaey EE, Hmed AA. Polyvalent Phage CoNShP-3 as a Natural Antimicrobial Agent Showing Lytic and Antibiofilm Activities against Antibiotic-Resistant Coagulase-Negative Staphylococci Strains. Foods. 2020;9(5):673. doi: 10.3390/foods9050673

79. Sofy AR, Hmed AA, Abd El Haliem NF, Zein MAE, Elshaarawy RFM. Polyphosphonium-oligochitosans decorated with nanosilver as new prospective inhibitors for common human enteric viruses. Carbohydr Polym. 2019;226:115261. doi: 10.1016/j. carbpol.2019.115261

80. McNicholl BP, McGrath JW, Quinn JP. Development and application of a resazurin-based biomass activity test for activated sludge plant management. Water Res. 2007;41(1):127-133. doi: 10.1016/j. watres.2006.10.002

81. Santhosh PB, Ulrih NP. Multifunctional super paramagnetic iron oxide nanoparticles: promising tools in cancer theranostics. Cancer Lett. 2013;336(1):8-17. doi: 10.1016/j.canlet.2013.04.032

82. Jayapaul J, Hodenius M, Arns S, et al. FMN-coated fluores-cent iron oxide nanoparticles for RCP-mediated targeting andlabeling of metabolically active cancer and endothelial cells. Biomaterials. 2011;32(25):58635871. doi: 10.1016/j.biomaterials.2011.04.056

83. Brunner TJ, Wick P, Manser P, et al. In vitro cytotoxicity of oxide nanoparticles: comparison to asbestos, silica, and the effect of particles solubility. Env Sci Technol. 2006;40(14):4374-4381. doi: 10.1021/es052069i 